Law \& Economics Working Papers

Law \& Economics Working Papers Archive:

2003-2009

Year 2009

\title{
Securities Class Actions Move North: A Doctrinal and Empirical Analysis of Securities Class Actions in Canada
}

\author{
Adam C. Pritchard* Janis P. Sarra ${ }^{\dagger}$
}

*University of Michigan Law School, acplaw@umich.edu

${ }^{\dagger}$ University of British Columbia, sarra@law.ubc.ca

This paper is posted at University of Michigan Law School Scholarship Repository.

http://repository.law.umich.edu/law_econ_archive/art101 


\title{
Securities Class Actions Move North: A Doctrinal and Empirical Analysis of Securities Class Actions in Canada
}

\author{
A.C. Pritchard, University of Michigan \& Janis P. Sarra, University of British Columbia ${ }^{1}$
}

\section{Introduction}

Securities fraud liability has been a consideration for Canadian companies for fifteen years now. In Canada, investors in public offerings have had a statutory cause of action for misrepresentation and failure to disclose material changes since the late 1970's; this cause of action became significant, however, when class action legislation was first introduced in Ontario in 1992. That legislation afforded plaintiffs financial support in the pursuit of such claims and a mechanism to reduce collective action problems. Yet there have been a modest number of cases and only one known case has been litigated to final judgment. During the same period, Canadian issuers cross-listed in the United States (US) have faced not only primary market civil liability, but also potentially much greater exposure for secondary market liability. The overwhelming majority of these secondary market cases settle prior to final judgment, but the settlement amounts are occasionally eye-popping. Nortel's recent $\$ 1$ billion plus settlement of suits is a notable example.

The size of potential settlements in secondary market class actions has made them a controversial feature of the US securities regime. One objection to such suits has been that they are sometimes an exercise in "pocket shifting". ${ }^{2}$ Shareholders are equally likely to be on the winning side of a fraudulent secondary market transaction as they are to be on a losing end, but the corporation is unlikely to accrue any benefit from secondary market transactions affected by misstatements. Notwithstanding this absence of benefit, the corporation often pays for the settlement directly or in the form of insurance premia for its officers. Hence in some cases, shareholders as residual claimants are essentially paying themselves for any misconduct. ${ }^{3}$ The objective of the class action is to influence the issuer's and others' behaviour, rather than shareholder behaviour, other than in respect of tipping or insider trading.

\footnotetext{
${ }^{1}$ The authors wish to thank the Toronto Stock Exchange Group for its generous support of this research project under the TSX Capital Markets Initiative. Thank you also to Tara Kyluik, UBC Law student for her research assistance. We thank Anita Anand, Mary Condon, and Jay Westbrook for helpful comments on earlier drafts.

2 This view could be contested on the basis of the liquidity of the market and existence of "in and out" investors.

${ }^{3}$ Settlements arguably come out of the assets of the corporation and the shareholders are entitled to a pro rata share of the residual value of the assets on wind-up of the company. See the discussion below.
} 
In 1995, the US Congress adopted legislation making it more difficult to bring such suits, but it failed to grapple with any pocket-shifting problem. More recently, a number of US studies have called for a rethinking of secondary market liability, calling it a major factor undermining the competitiveness of the US capital markets. ${ }^{4}$

Notwithstanding these concerns about the US system, secondary market class actions have now come to Canada. On December 31, 2005, the secondary-market civil liability provisions became effective in Ontario, followed by five other Canadian provinces enacting almost identical amendments to their securities legislation effective 2007 and $2008 .^{5}$ The amendments are significant in that $95 \%$ of capital markets activity in Canada is in the secondary market; hence the possibility of remedies for investors and potential liability for issuers, corporate officers, and other specified persons is considerably more significant than under primary market civil liability provisions. The first six applications for class actions invoking the new secondary-market civil liability provisions have now been filed.

This paper analyses securities class actions in respect of Canadian issuers since the class action legislation was adopted. Although civil remedies have been the subject of considerable scholarly commentary, there has not, to the authors' knowledge, been a systematic analysis of cases in which Canadian issuers have been sued in Canada and the US in terms of the types of claims and their disposition, with a comparative analysis of similar claims in the US. The study drew on the TSX Datalinx data, the Stanford Class Action database, the CBA class action database, reported judgments, and interviews with class action counsel for both plaintiffs and defendants. ${ }^{6}$ It analyzes the nature of alleged claims, the quantum of relief sought, and the outcome of proceedings. Insights from these primary-market and secondary market cases may inform some

\footnotetext{
${ }^{4}$ The SEC has announced that they will hold a roundtable to address the topic, although it has yet to be scheduled.

5 Ontario, Part XIII, Ontario's Securities Act, RSO 1990, c. S.5, in force December 31, 2005; Alberta Securities Amendment Act, 2006, S.A. 2006, c. 30 received Royal Assent, May 24, 2006, proclaimed in force on December 31, 2006; http://www.albertasecurities.com/dms/2992/14397/15281 2390579 v1 ASC NOTICE OF AMENDTS TO PART 16.1 ASC RULES (GEN)- EFF DEC 31,06.pdf. Manitoba The Securities Amendment Act, S.M. 2006 , c. 11, in force on January 1, 2007; http://www.msc.gov.mb.ca/legal docs/legislation/notices/2006 34 bill 17 notice.html; Saskatchewan The Securities Amendment Act, 2007, in force January 1, 2008; http://www.sfsc.gov.sk.cal; Québec Civil Code, R.S.Q., c. C-25 and Québec An Act to amend the Securities Act and other legislative provisions, Statutes of Québec, 2007, Chapter 15, effective November 9, 2007; British Columbia Securities Amendment Act, $3^{\text {rd }}$ Session, 38 ${ }^{\text {th }}$ Parliament, introduced April 18, 2007, Royal assent on November 22, 2007, not yet proclaimed in force as of April 15, 2008, http://www.leg.bc.ca/38th3rd/1st read/gov28-1.htm.

5 Alberta Securities Commission, The Alberta Capital Market: A Comparative Overview, 2007, (ASC, May 2007), at 4, based on TSX data as of December 31, 2006; http://www.albertasecurities.com/dms/6115/6116/15825 ASC Cap Market Review.pdf.

${ }^{6}$ The authors acknowledge with thanks the use of the TSX Datalinx data and that of the Stanford Class Action database.
} 
of the issues that will arise in the Canadian secondary-market civil liability cases. Our working hypothesis was that the seriousness of the allegations would influence the types of suits filed and would generate a larger settlement amount. Although the study found that the seriousness of allegations does seem to signal the likelihood of a suit, contributing factors to the amount of settlement appear to be jurisdictional complexity, the different cost regimes, and the number of parties seeking a remedy.

Another working hypothesis was that the availability of new secondary market civil liability provisions may affect the pricing and availability of director and officer (D\&O) insurance. There is little understanding of how insurance factors into settlement of class action suits and the availability of D\&O insurance. ${ }^{7}$ The study sought to examine how D\&O insurance premia may be an indicator of the expected cost of securities litigation, given that litigation expenses in securities class actions typically are paid from directors' and officers' liability insurance policies. The paper reports on data collected in respect of D\&O insurance premia for 2004 to 2006, making some preliminary observations in respect of whether the introduction of this new liability exposure has had a significant effect on the price of insurance. We find that Canadian companies listed only in Canada experienced a substantial drop in D\&O coverage from 2004 to 2005, while premia remained relatively steady. At the same time, Canadian firms listed in the US experienced little change in their coverage amounts, but a general reduction in their premia. This data suggests that Canadian-listed firms suffered a price increase for their D\&O coverage relative to their counterparts who were also listed in the US, although, as discussed below, there are complex factors affecting the price and availability of such insurance.

Part II of the paper sets out the context for the study and examines the development of civil liability remedies and class proceedings legislation and their influence on one another. Part III then analyses the substance and effect of the statutory framework through an empirical examination of the suits filed against Canadian issuers in Canada and the US. Part IV analyses the effect of the secondary market legislation on D\&O coverage and premia for those companies. Appendices $A$ and $B$ provide a helpful summary chart of the differences between Canadian and US primary market and secondary market civil liability provisions.

\section{Context for the Study}

\footnotetext{
${ }^{7}$ One effort to explore this is issue is Tom Baker and Sean Griffith, How the Merits Matter: D\&O Insurance and Securities Settlements (Fordham Law School Working Paper, 2008).
} 
Canadian capital markets are somewhat unusual in that they are regulated only on a provincial and territorial basis. By contrast, in the US, most regulation occurs at the federal level under its federal/state system. Although there are 13 provincial regulators, $92 \%$ of all issuers in Canadian capital markets are based in Ontario, Alberta, British Columbia and Québec. ${ }^{8}$ In the US, state securities regulators play a relatively insignificant role, with most regulatory authority wielded by the federal Securities and Exchange Commission (SEC). ${ }^{9}$

$86 \%$ of the aggregate market capital of companies listed on Toronto Stock Exchange (TSX), which is Canada's senior equities market, and the TSX Venture Exchange (TSXV), Canada's junior equities market, are located in these same four provinces. ${ }^{10}$ The aggregate market capital of companies listed on the TSX and TSXV was $\$ 2.12$ trillion in 2006. ${ }^{11}$ Canadian-based companies represent approximately $96 \%$ of the companies listed on the two exchanges and $92 \%$ of the aggregate market capital of public companies; hence foreign companies do not currently represent a significant component of TSX or TSXV listings. ${ }^{12}$ Based on aggregate market capital of companies with head offices in the respective provinces, the largest provincial capital markets are Ontario at $41 \%$, Alberta at $26 \%$, Québec at $11 \%$ and British Columbia at $8 \%{ }^{13}$ The aggregate market capital of companies listed on the two primary US exchanges, the New York Stock Exchange and Nasdaq is $\$ 26.6$ and $\$ 4.1$ trillion, respectively. ${ }^{14}$ Of the 2,600 companies listed on the NYSE, 83 are Canadian issuers. ${ }^{15}$ Of the 3,200 companies listed on the Nasdaq, 68 are Canadian. $^{16}$

Both Canadian and US securities law seek to protect investors and promote investor confidence and market integrity. ${ }^{17}$ Market integrity is measured, in part, by market efficiency. The provincial Canadian statutes are similar, requiring the registration of persons involved in the securities business, prospectus disclosure on the distribution of securities, continuous disclosure of information after the distribution of securities, insider trading regulation, and takeover bid

\footnotetext{
${ }^{8}$ Alberta Securities Commission, The Alberta Capital Market: A Comparative Overview, 2007, (ASC, May 2007), at 4, based on TSX data as of December 31, 2006; http://www.albertasecurities.com/dms/6115/6116/15825_ASC_Cap_Market_Review.pdf

${ }^{9}$ A Guide to the NYSE Marketplace (2006), http://www.nyse.com/pdfs/nyse bluebook.pdf. However, state regulators can be highly involved in regulating small cap companies.

${ }_{11}^{10}$ Alberta Securities Commission, supra, note 8 at 4.

11 Ibid.

12 Ibid.

13 Ibid.

${ }_{14}^{14}$ A Guided to the NYSE Marketplace (2006): Nasdaq Annual Report (2006).

15 http://www.nyse.com/about/listed/listed.html

${ }^{16} \mathrm{http}: / /$ www.nasdaq.com/reference/NASDAQ\%20Global\%20Platform\%20-\%20Fact\%20Sheet.pdf.

17 Pezim v. British Columbia (Superintendent of Brokers), [1994] 2 S.C.R., Kerr v. Danier Leather Inc. 2007 SCC 44 at para. 32. The Supreme Court of Canada has held that securities statutes protect investors the risks of an unregulated market, and by its assurance of fair dealing and by the promotion of the integrity and efficiency of capital markets it enhances the pool of capital available to entrepreneurs.
} 
regulation. ${ }^{18}$ Mandatory disclosure is the major form of regulation imposed by both jurisdictions, although the models differ as Canada has adopted a continuous disclosure regime whereas the US has only a periodic disclosure regime. Liability concerns are one reason why the US has not adopted a continuous disclosure requirement. Disclosure requirements impose costs on issuers, so a major public policy challenge has been to strike an appropriate balance between the costs and benefits of increased disclosure obligations. Other parts of the system, marketplace regulation and oversight of brokers an dealers also advance the statutory objectives.

The new civil liability provisions create a statutory right of action in favour of secondary market investors against issuers and key related persons for making public misrepresentations about the issuer or for failing to disclose material changes as required by securities law. The provisions, together with existing authority by securities regulators to take action when issuers breach securities law, seek to prod directors, officers and other persons of influence or control to ensure that the issuer meets its continuous disclosure obligations. Ostensibly, civil liability provisions are also aimed at compensation of individuals through redress for harms caused by the action or inaction of issuers in violation of securities law. In contrast, regulatory public enforcement powers are largely aimed at deterrence of misconduct. Arguably, however civil liability, public enforcement and quasi-criminal sanctions together provide an integrated approach that promotes investor protection, investor confidence and market integrity through both deterrence and compensation. $^{19}$

\section{Relationship between Securities Law Civil Liability Provisions and Class Action Statutes}

Under common law, investors must base a claim concerning a misrepresentation on the common law action of negligent misrepresentation, which is difficult and costly to establish as investors must prove reliance and loss causation. In similar actions in the United States under Exchange

\footnotetext{
${ }^{18}$ Although Ontario's Securities Act, RSO 1990, c. S.5, has been amended a number of times over the last few years, the basic principles and structure relatively unchanged since 1978 reforms. The Canadian Securities Administrators (CSA), an umbrella organization of provincial and territorial securities regulators, promulgates instruments as a mechanism to reduce duplication required of market participants in matters where an issuer wants to sell securities in more than one province. A national instrument (NI) is one that has been agreed to by all provinces and territories and a multilateral instrument (MI) has been agreed to by some but not all of the provinces, which results in a lack of consistency in regulation across Canada. However, the instruments do not themselves have legal force; they must be implemented by rule or policy in each participating province, an important but technical requirement once provinces agree to be bound. Key instruments include National Instrument 51-102 Continuous Disclosure Obligations; there are also sector specific disclosure instruments. The CSA also creates and operates mutual reliance review systems for prospectus review, continuous disclosure review, registration, and exemptive relief applications.

19 There is an active debate in Canada regarding the precise goals of public and private enforcement of securities law, and more specifically, whether Canada should move towards more of a compliance culture based system rather than the current deterrence based system. For a discussion, see Mary Condon, "Rethinking Enforcement and Litigation in Ontario Securities Regulation" (2006) 32 Queen's L.J. 1.
} 
Act Rule 10b-5, courts have accepted proof of reliance on the basis of a "fraud-on-the-market" theory, which suggests that the market is efficient in the semi-strong form and hence the market price will quickly reflect information contained in disclosure documents. ${ }^{20}$ Fraud on the market has been expressly rejected by Canadian courts. ${ }^{21}$

In response to the hurdles posed by the negligent misrepresentation cause of action, the Canadian primary market statutory civil liability regime was enacted in the late 1970s to provide accessible remedies for harms to investors. In relation to primary offerings, the requirement under most Canadian securities statutes is for the prospectus to provide "full, true and plain disclosure of all material facts" relating to the securities being distributed, as well as to comply with all applicable statutory requirements. ${ }^{22}$ However, given the cost barriers to bringing suits and collective action problems of investors, the primary market civil liability provisions were little used for a number of years. Some of those hurdles were removed by the introduction of class action proceedings statutes in some Canadian jurisdictions in the early to mid 1990s, most notably Ontario and British Columbia. ${ }^{23}$ Other jurisdictions have only recently enacted class proceedings legislation; the Alberta provisions have been in force for three years, Newfoundland for five years, and New Brunswick only one year. ${ }^{24}$ The highly staggered introduction of class proceedings legislation may explain part of the reason why there have not been more primary market class actions in Canada. The US pattern was similar, but much earlier; a primary market liability provision was included in the Securities Act of 1933, but it was little used until the rules relating to class actions were relaxed in 1966.

\footnotetext{
20 The underlying notion of a semi-strong form is that the market quickly assimilates and reflects material changes through price adjustments in share value. The investor is said to rely on the market price and thus implicitly relies on any misrepresentations in continuous disclosure documents that are reflected in the market price. See Basic, Inc. v. Levinson, 485 U.S. 224 (US 1988).

${ }^{21}$ Carom v. Bre-X Minerals Ltd., [1998] O.J. No. 4496 (Ont. C. J. (Gen. Div.), in which the court held at paras 39-40: "39] The adoption of the fraud on the market theory by an Ontario court cannot be justified where neither the statutory duty, the cause of action founded upon its breach, nor the predominance test as a procedural barrier to class proceedings exist. More so, the plaintiffs seek to apply the theory to common law causes of action, to which it would not be applicable in the United States, and in a wholesale fashion, without the restrictions which circumscribe it there. Simply put, the proposition advanced is ill-conceived. 40]... In my view, the presumption of reliance created by the fraud on the market theory can have no application as a substitute for the requirement of actual reliance in either tort."

${ }_{22}$ NI 41-101 General Prospectus Requirements, March 7, 2008,Volume 31, Issue 10 (Supp-2), (2008), 31 OSCB.

${ }^{23}$ For example, the Ontario Class Proceedings Act (OCPA) came into effect on January 1, 1993 and the British Columbia Class Proceedings Act, RSBC 1996, c. 50, came into force in 1996. There are also provisions allowing for a sub-class representative plaintiff or defendant for protection of their interests where there are common issues not shared by all class members, s. 5(2), OCPA.

${ }^{24}$ Alberta Class Proceedings Act, in force 1 April 2004; Newfoundland Class Actions Act, SNL 2001, c. C18.1; New Brunswick Class proceedings Act, SNB, C5.15 (2006), in force 30 June 2007. Nova Scotia has a Class Proceedings Act that received Royal Assent on December 13, 2007, but has not been proclaimed in force as of 12 April 2008. Prince Edward Island does not have any statute.
} 
Class actions allow investors with common interests to have their claims determined in a single court proceeding brought by representative plaintiffs of the class, reducing the economic barriers of individuals bringing such actions. Class actions allow the courts a mechanism to resolve such claims efficiently and cost-effectively and the court serves a gatekeeping function in that it must certify proceedings before they can proceed. ${ }^{25}$ The legislation varies across Canada in that some regimes are opt-in regimes, whereas others are opt-out. For example, the British Columbia, Newfoundland and New Brunswick class action legislation are opt-in regimes; the class is comprised of residents in the jurisdiction unless non-residents opt in to a class action. Other statutes create a national opt-out jurisdiction. ${ }^{26}$ Ontario has an opt-out regime and any member of a class involved in a class proceeding may opt out of the class within the time specified in a certification order. ${ }^{27}$ Saskatchewan had an opt-in regime until this year; with proclamation of Saskatchewan's The Class Actions Amendment Act, effective April 1, 2008, Saskatchewan has become an extra-provincial opt-out jurisdiction with a new regime for handling national class actions.

In certifying a class action, the court must be satisfied that the pleadings disclose a cause of action; that there is an identifiable class of persons that could be represented; that the claims raise common issues that preferably should be resolved together; and that there is a representative plaintiff or plaintiffs who would fairly and adequately represent the interests of the class without conflict of interest and who has a workable plan for advancing the proceeding. ${ }^{28} \mathrm{~A}$ class action proceeding can only be settled or discontinued with the approval of the court. ${ }^{29}$

The Canadian class proceedings statutes set out provisions to aid the courts in determining both common issues and individual remedies where liability is found. Where the participation of individual class members is required to determine individual issues, the court can determine the issue itself or order a claims adjudication procedure. Some Canadian class action statutes direct the judge to choose the least expensive and most expeditious method of determining the issues that is consistent with justice to class members and the parties. ${ }^{30}$

\footnotetext{
${ }^{25}$ See for example, ss. 1, 2, OCPA. A defendant to two or more proceedings may also make a motion for an order certifying the proceeding as a class proceeding and appointing a representative plaintiff. See for example, ss. 3, OCPA. Similarly, a party to a proceeding with two or more defendants may make a motion at any stage of proceedings for an order certifying the proceeding and appointing a representative defendant. See for example, ss. 4, OCPA. These provisions are generally consistent with US practice under the Federal Rules of Civil Procedure Rule 23.

${ }^{26}$ Newfoundland, s. 17(2); New Brunswick, s. 18(3).

27 OCPA, s. 9.

28 See for example, Ontario Class Proceedings Act, S.O. 1992, c. 6, s. 5 (OCPA).

${ }^{29}$ OCPA s. 29(1) and (2).

30 See for example, OCPA, s. 25.
} 
There are differences in disclosure obligations under the different provincial class action statutes. In Québec, for example, there is no compulsory disclosure of documents until after discovery, although courts will consider making a safeguard order. ${ }^{31}$

Under the Canadian statutes, the court must approve any agreement respecting fees and disbursements between a solicitor and a representative party. ${ }^{32}$ Class members, other than the representative party, are not liable for costs except with respect to determination of their own individual claims. ${ }^{33}$ The Ontario Class Proceedings Act permits the solicitor to make a motion to the court to have his or her fees increased by a multiplier as fair and reasonable compensation for the risk incurred in undertaking and continuing the proceeding under a contingency fee agreement. $^{34}$ The Ontario Court has observed that lawyers and their clients are permitted to engage in special fee arrangements for class action proceedings, subject to the court having final control over all agreements. ${ }^{35}$ The court will consider the reasonableness of the fee and can consider the manner in which the solicitor conducted the proceeding. ${ }^{36}$ In contrast, British Columbia has not adopted such provisions in its legislation and has expressly declined to award multiplier fees in securities law class action suits as undesirable and unnecessary. ${ }^{37}$ This different approach to fees may create incentives for plaintiff counsel to commence actions only in jurisdictions where the range of potential fees is considerably higher. US law allows for substantial multipliers in securities class actions, although the legislation limits the attorneys' recovery to a "reasonable percentage" of the amount paid to the class members. ${ }^{38}$ The

\footnotetext{
${ }^{31}$ Option des consommateurs (Benoît Fortin) v. Amex Bank et al, Que. S.C. (February 2007); Union des consommateurs v. Union Canadienne et al, Que. S.C. (2004).

${ }^{32}$ The agreement must be in writing and specify the terms, an estimate of expected fees, whether the arrangement is contingent on success of the class proceeding or not; and state the method by which payment is to be made. OCPA ss. 32, 33. Amounts owing are enforceable as a first charge on any settlement funds or monetary award, OPCA, s. 32(2). Section 33 specifies that despite the Solicitors Act and An Act Respecting Champerty, the parties may enter into a written agreement providing for payment of fees and disbursements only in the event of success in a class proceeding, defined as a judgment on the common issues in favour of some or all of the class members and a settlement that benefits one or more class members.

${ }_{33}$ OPCA, s. 31(2).

${ }^{34}$ OPCA ss. 33(3) to (9).

${ }^{35}$ Epstein v. First Marathon Inc., [2000] 2 B.L.R. (3d) 30 (Ont. S.C.) at para. 36, citing the comments of then Attorney General Ian Scott, (Ontario, Legislative Assembly, Debates, 21 June 1990) and citing Mr. Winninger, on behalf of Attorney General Howard Hampton, Ontario, Legislative Assembly, Debate (18 November 1991) at 350-6) [second reading, November 18, 1991].

${ }^{36}$ OPCA ss. 33(8) and (9).

${ }^{37}$ Pearson v. Boliden Ltd. [2006] B.C.J. No. 1512 (B.C.S.C.), in which the Court held that fees should be assessed based on the fairness and reasonableness in the circumstances. Section 66 of the Legal Profession Act, R.S.B.C. 1998, c. 9 governs contingency fee agreements, s. 68(6) of the Act allows the Registrar to modify or cancel the agreement if it is found to be unreasonable or unfair "under the circumstances existing at the time the agreement was entered into", and that the Court has jurisdiction to review the reasonableness of solicitors' fees arising out of contingency fee agreements as well as the parens patriae jurisdiction to ensure the reasonableness of legal fees incurred on behalf of class members who are under legal disability,

${ }^{38}$ Securities Exchange Act $\S 21 \mathrm{D}(\mathrm{a})(6)$.
} 
percentage agreed to by the lead plaintiff at the time that counsel was engaged carries presumptive weight. ${ }^{39}$

In both Canada and the US, there has been concern about class action counsel generating class actions without a representative plaintiff that is truly giving direction to counsel in the proceeding. Professor Garry Watson has expressed concern about "entrepreneurial lawyers" that initiate and run the class action, often with a view to maximizing their own financial return to the potential prejudice to class participants and to the integrity of the class action system. ${ }^{40}$ Although entrepreneurial lawyers facilitate the access to justice goals of class actions, Watson suggests that the desire to maximize financial amounts may lead such counsel to refuse reasonable offers of settlement, or alternatively, may encourage counsel to seek a settlement that fully covers their expenses and remuneration but results in an inadequate or unfair remedy for investors. ${ }^{41}$ The Ontario Court has noted that class proceedings raise certain ethical issues, such as the potential conflict of interest between the lawyer's duty to the representative plaintiff and to other members of the class. ${ }^{42}$

Five Canadian jurisdictions have a no-cost regime, British Columbia, Saskatchewan, Manitoba, Newfoundland and Labrador and the Federal Court, in which each side in a class action bears their own costs, except where there is misconduct or injustice in the proceeding. ${ }^{43}$ For example, the British Columbia provision specifies that:

37 (2) A court referred to in subsection (1) may only award costs to a party in respect of an application for certification or in respect of all or any part of a class proceeding or an appeal from a class proceeding

(a) at any time that the court considers that there has been vexatious, frivolous or abusive conduct on the part of any party,

(b) at any time that the court considers that an improper or unnecessary application or other step has been made or taken for the purpose of delay or increasing costs or for any other improper purpose, or

(c) at any time that the court considers that there are exceptional circumstances that make it unjust to deprive the successful party of costs. ${ }^{44}$

${ }^{39}$ See, e.g., In re Cendant Corp. Litigation, 264 F.3d 201 (3d Cir. 2001).

${ }^{40}$ Garry Watson, "Class Actions and the Dilemma of 'Entrepreneurial Lawyering': The Good and the Not So Good Aspects of Class Actions" (unpublished 2005, on file with authors) at 5.

${ }^{41} \mathrm{Ibid}$. at 6, 7. Watson argues that a sensible method for class action counsel to be remunerated for the time expended and risks taken is essential to a workable and vigorous class action regime.

42 Epstein v. First Marathon Inc., supra, note 35 at para. 37, citing Attorney General Howard Hampton, Ontario, Legislative Assembly, Debate (27 April 1992) at 372.

${ }^{43}$ British Columbia Class Proceedings Act R.S.B.C. 1996, c. 50, c. 37; Saskatchewan Class Actions Act, S,S. 2001, c. C-12.01, s. 40; Manitoba Class Proceedings Act, C.C.S.M., c. C130, s. 37; Newfoundland and Labrador Class Actions Act, S.N.L. 2001, c. C-18.1, s. 37; Federal Court Rules, Rule 299.41. These provinces have followed the Uniform Law Conference of Canada recommendations for a no-cost regime in respect of class action proceedings; Uniform Class Proceedings Act (Model Law Consolidated 2006), s. 37(2), http://www.ulcc.ca/en/us/Class Proceedings Act Consolidation En.pdf, March 21, 2008.

${ }^{44}$ British Columbia Class Proceedings Act , ibid. at 37(2). 
Hence, in five provinces, plaintiffs have considerable protection against the cost consequences if they do not win. In contrast, New Brunswick and Alberta class action legislation specifies that ordinary rules of court in respect of costs apply. ${ }^{45}$ Québec has a cost regime, but limits it by specifying that the amount of costs against a plaintiff will be limited by the tariff normally applied to plaintiffs in small claims court. ${ }^{46}$ Ontario generally has a cost regime, although s. 31(1) of the Ontario legislation specifies that "In exercising its discretion with respect to costs under subsection 131 (1) of the Courts of Justice Act, the court may consider whether the class proceeding was a test case, raised a novel point of law or involved a matter of public interest" ${ }^{47}$ However, Klein and Lennox observe that the cost consequences are potentially much greater in Ontario, because the fees tariff is much higher than in the rest of Canada; because the courts have been uneven in how they apply the s. 31(1) provision in exercising their jurisdiction to award costs against representative plaintiffs; and because there is an uncertainty under Ontario caselaw in respect of whether or not plaintiff's counsel should be indemnifying the representative plaintiff, an important factor in determining cost risk. ${ }^{48}$

The regimes with potential cost consequences in combination with the timing of class proceedings legislation may have limited the number of primary market actions filed to date. Also limiting the number of actions to date is the fact that the primary market only comprises $5 \%$ of the Canadian capital market..

Several Canadian jurisdictions have created class proceedings funds to assist with the potential barriers created by the costs of class action proceedings. These funds pay for disbursements related to the proceeding. ${ }^{49}$ Although the Ontario Class Proceedings Fund is not available for fees of plaintiff counsel, it does facilitate class actions on a contingency fee basis as the risk to

\footnotetext{
${ }^{45}$ Alberta Class Proceedings Act, S.A. 2003, c.C-16.5, s. 37; New Brunswick Class Proceedings Act, S.N.B. 2006, c.5.15, c. 39.

${ }^{46}$ D. Klein and D. Lennox, "Class Action Cost Regimes in Canada", 2008, on file with author.

${ }^{47}$ OCPA, s. 31(1). Ontario Courts of Justice Act, R.S.O. 1990, c. C.43; Ontario Rules of Civil Procedure, R.R.O. 1990, Reg. 194, in which the court is to consider principles of indemnity, the reasonable expectation of parties, the complexity of the proceeding, the conduct of litigation and the importance of the issue.

${ }^{48}$ Klein and Lennox, supra, note 46 at 3, citing a number of cases outside of the securities law context in which the cost awards in certification applications have exceeded $\$ 100,000$.

49 See for example, Ontario Law Society Act, R.S.O. 1990, c. L. 8, as amended, s. 59.1 (OLSA); http://www.e-laws.gov.on.ca/html/statutes/english/elaws statutes 90108 e.htm; Law Society Amendment Act, (Class Proceedings Funding), 1992, amending the Ontario Law Society Act, ibid. and Regulation 771/92; Class Proceedings Practice Directions \#1 and \#2; Hansard Legislative Debates, June 12, 1990, http://www.ontla.on.ca/house-proceedings/transcripts/files html/1992-05-04 1016.htm. Québec Fonds d'aide aux recours collectifs, An Act respecting the class action (R.S.Q., c. R-2.1, s. 38, par. a) and Regulation Gazette officielle of 23 February 2008, c. R-2.1, r.3.1, Regulation respecting the percentage withheld by the Fonds d'aide aux recours collectifs. In Ontario, the Class Proceedings Fund was initially endowed with $\$ 500,000$. Its resources are now $\$ 6$ million.
} 
plaintiff counsel is time and energy, not the full costs of the proceeding. ${ }^{50}$ A defendant to a class action proceeding may also apply for payment from the Ontario Class Proceedings Fund in respect of a costs award made in the proceeding in the defendant's favour against a plaintiff that has received financial support from the Fund. ${ }^{51}$ This provision provides significant protection to the plaintiff, given the Canadian cost rule of costs following the event, as it provides a form of cost indemnification if the plaintiff is not successful. Thus the Committee that approves class action funding plays a partial gate-keeping role; it considers the merits of a case before awarding access to the Fund, the likelihood that it will be certified, the public interest engaged and the plaintiff's efforts to raise funds. ${ }^{52}$ Although a negative decision does not prevent a representative plaintiff from proceeding, it may signal problems with the action as framed and create a cost barrier. ${ }^{53}$ The case may be meritorious, however, but not engage the public interest.

A plaintiff must make a separate application for financial assistance in respect of each stage in a proceeding, including, steps taken up to the end of the certification hearing; steps taken up to the end of discovery or cross-examination on affidavits; further steps concerning the determination of common issues; financial support for experts; and any appeals from a judgment. ${ }^{54}$ There are disclosure and notice requirements associated with receipt of the funds. ${ }^{55}$ When a monetary award or settlement occurs, there is a levy of $10 \%$ of the amount of the award or settlement funds. ${ }^{56}$ The levy allows the Fund to be replenished so that it has resources to fund future class actions. Where representative plaintiffs and their counsel do not wish to have that amount levied, they do not make an application to the Fund, but rather, carry the costs themselves.

In the US, the expenses of the proceeding are borne by plaintiffs' counsel and recovered only if the plaintiff prevails. Cost shifting is permitted only in narrow circumstances, chiefly "abusive litigation". 57

\footnotetext{
${ }^{50}$ OLSA s. 59.5(1). The Committee is made up of Government appointed and Ontario Law Foundation appointed members. specifying that the Committee may consider the extent to which the issues in the proceeding affect the public interest, and if the application for financial support is made before the proceeding is certified as a class proceeding, the likelihood that it will be certified.

${ }^{53}$ Although securities law cases are not separated out from other class proceedings, to date, Ontario has funded 29 applications involving 78 suits and has denied or deferred 23 applications. The fund was established with $\$ 500,000$ and now has $\$ 6.5$ million as of December 31, 2007; Class Proceedings Committee, Annual Report, December 31, 2007.

${ }^{54} \mathrm{Ibid}$. ss. $2,4$.

55 Ibid. ss. $6-9,12,13$. This includes a requirement that the plaintiff notify the other class members, if the class is certified, that the recipient has received financial support from the Class Proceedings Fund in respect of the proceeding; and that there will be a levy that reduces the amount of any award or settlement funds to which the class members may become entitled. The Committee can ask the plaintiff to repay amounts where the action is discontinued or abandoned, s. 9 .

${ }^{56}$ Ibid. s. 10.

${ }^{57}$ Securities Exchange Act $\S 21 \mathrm{D}(\mathrm{c})$.
} 
The issue of costs awards against unsuccessful plaintiffs is somewhat unsettled currently, as the only case that has made it to final judgment, Kerr v. Danier Leather Inc., resulted in a cost award against the representative plaintiff of more than one million dollars. ${ }^{58}$ Kerr v. Danier Leather was a primary market civil action that was ultimately dismissed by the Supreme Court of Canada. The sole representative plaintiff in the class action, Durst, had sought an order that no costs should be awarded against him having regard to s. 31(1) of the Ontario Class Proceedings Act, 1992, should the class action proceeding fail.

The Supreme Court of Canada held that there was no error in principle that would justify intervening in the costs order made by the Ontario Court of Appeal. ${ }^{59}$ The Court held that although the resolution of the dispute would affect future actions for prospectus misrepresentation, in essence the case was "a commercial dispute between sophisticated commercial actors who are well resourced" and that "converting an ordinary piece of commercial litigation into a class proceeding may be seen by some observers simply as an in terrorem strategy to try to force a settlement" ${ }^{60}$ The Supreme Court held that the Ontario Class Proceedings Act, 1992 expression "matter of public interest" in s. 31(1) involves either issues of broad public importance or persons who are historically disadvantaged in society. It found that the proceeding before it was a dispute where private commercial interests predominated and that this was not a case where people on either side were historically disadvantaged or there was a power imbalance. ${ }^{61}$ The Court held that general concerns about access to justice did not, in this case, warrant a departure from the usual cost consequences and that it should not be assumed that class proceedings invariably engage access to justice concerns to an extent sufficient to justify withholding costs from the successful party. ${ }^{62}$

The Supreme Court of Canada judgment gives little weight to the significance of the Court of Appeal's findings on deference to business judgment. That aspect of the lower court decision arguably raised a policy question of broad public importance whereby leaving the Court of Appeal judgment intact could have resulted in considerable uncertainty in the market in respect of the interplay between statutory disclosure requirements and deference to business judgments. The Supreme Court's clarification of this issue is significant, and should have been a consideration in the cost decision.

The judgment may create some disincentive to bringing class proceedings, given the potential cost consequences. Although the courts may be less inclined to award costs against

\footnotetext{
${ }^{58}$ Kerr v. Danier Leather Inc., 2007 SCC 44.

59 Ibid. at para. 61.

${ }^{60} \mathrm{lbid}$. at para. 67.

${ }^{61} \mathrm{Ibid}$. at para. 67

$62 \mathrm{lbid}$. at para. 68.
} 
disadvantaged investors, those investors are not the most likely people to bring securities class action proceedings. It is the more affluent and knowledgeable investors that are likely to pursue such claims. Institutional investors, such as pension funds, have been key plaintiffs in US securities class actions in recent years. The court's future consideration of costs may also depend on whether the investors allegedly harmed by the impugned conduct have invested disposable cash or whether the investment represents retirement or other significant savings, given the link the court makes between public interest and historical disadvantage in determining cost issues. The finding clearly has significance for secondary market civil actions as the first cases move forward. Yet since the Kerr v. Danier Leather judgment, there have been a number of new cases filed, suggesting that may not have acted as a deterrent; but rather, may have forced counsel and representative plaintiffs to bring forward only the most meritorious claims. The judgment may also change the dynamic of settlement talks, as the fear of cost awards may drive plaintiffs to settle as much as fear of litigation costs drives the issuer side in settlement talks.

One issue raised by the Supreme Court of Canada judgment is whether the court should take into consideration the amount of litigation generated by the defendants in a prolonged case. The Court held that while there is a strong public interest in setting the rules of adequate disclosure, regard must also be had to the situation of the defendants, who had incurred the costs of 50 hearing days. Even if one accepts the court's view that the plaintiff was a well resourced individual, there is some question as to whether a plaintiff should have to bear the full costs of defendant interlocutory and other motions to delay or discourage litigation. There may be need to apportion court costs in such a manner that recognizes the conduct of the parties and allocates expenses on a reasonable basis. Interestingly in Kerr v. Danier Leather, the Court did not attach weight to the fact that the plaintiff was truly a representative plaintiff in that he commenced and pursued the action; he was not the product of a search by class action counsel for a convenient representative plaintiff.

The availability of access to a no cost regime, particularly in those jurisdictions that are opt-out regimes, may influence where the first secondary market civil liability cases will be brought. To date, most have been brought in Ontario, notwithstanding Kerr v. Danier Leather Inc.

\section{Brief History of the Secondary Market Civil Liability Provisions}

The enactment of civil liability provisions in respect of secondary market disclosure was more than three decades in the making. Over a period of almost thirty years, there had been a number of proposals to extend statutory civil liability to continuous disclosure, to align remedies arising out of secondary market transactions with those available for primary market transactions. In 1979, the federal Proposals for a Securities Market Law of Canada recommended a statutory civil 
liability regime covering continuous disclosure. ${ }^{63}$ In 1984, the Ontario Securities Commission (OSC) recommended the same. ${ }^{64}$ In 1994, the Toronto Stock Exchange (TSX) Committee on corporate governance recommended that the issue of civil liability remedies in respect of timely and continuous disclosure should be placed again on the public policy agenda. ${ }^{65}$ Statutory civil actions were also recommended by the TSX Committee on Corporate Disclosures (the "Allen Committee") final report issued in $1997 .{ }^{66}$ Although these reports did not result in immediate amendments, their cumulative effect was to create momentum for legislative change.

The contours of the new statutory civil liability regime are based on draft legislation that the Ontario Securities Commission (OSC) and Canadian Securities Administrators (CSA) proposed for public comment in 1998 and 2000, based on the Allen Committee recommendations. ${ }^{67}$ That draft legislation became the subject of further public policy debate, a major concern being potential costs to issuers and their directors of having to defend against unmeritorious class actions. ${ }^{68}$ The leave requirements eventually adopted were an outcome of that process, and together with the "loser pays" cost regime in Ontario and proportionate liability provisions, the leave provisions are viewed as discouraging the use of the statutory right of action to bring coercive strike suits. ${ }^{69}$ Ontario's introduced its legislation in the form of Bill 198 in November

\footnotetext{
${ }^{63}$ P. Anisman, J. Howard, W. Grover \& J.P. Williamson, Proposals for a Securities Market Law for Canada (Ottawa: Minister of Supply and Services, Canada, 1979).

64 "Civil Liability for Continuous Disclosure Documents Filed under the Securities Act - Request for Comments" (1984), 7 OSCB 4910. Similarly, in 1994 the B.C. government developed a proposal to introduce a limited scheme of civil liability for certain disclosure in response to the Matkin Inquiry and recommendations reflected in the Matkin Report (J.G. Matkin \& G.G. Cowper, Restructuring for the Future; Towards a Fairer Venture Capital Market, Report of the Vancouver Stock Exchange \& Securities Regulation Commission (1994)). However, at the time, the Allen Committee had been established and the B.C. government agreed to await the release of that committee's report with the aim of aligning provisions for adoption nationally.

65 "Where Were The Directors? Guidelines for Improved Corporate Governance in Canada", Report of The Toronto Stock Exchange Committee on Corporate Governance in Canada (December, 1994) (the "Dey Committee").

66 The Allen Committee was established to review the adequacy of continuous disclosure by Canadian issuers. Its report concluded that there was evidence of a significant number of incidents of disclosure violations, expressing concern about loss of both investor confidence and reputation of Canadian capital markets. In 1999, the Mining Standards Task Force endorsed the Allen Committee recommendation of statutory civil liability for misleading continuous disclosure as an important step towards ensuring effective accountability of companies for disclosure relating to mineral exploration, development and production. The Toronto Stock Exchange Committee on Corporate Disclosure, Final Report, Responsible Corporate Disclosure - A Search for Balance (March 1997) (the "Allen Committee Report"); Mining Standards Task Force, Setting New Standards: Recommendations for Public Mineral Exploration and Mining Companies, January 1999.

67 See CSA Notice 53-302 - Proposal for a Statutory Civil Remedy for Investors in the Secondary Market and Response to the Proposed Change to the Definition of "Material Fact" and "Material Change" (2000), 23 OSCB 7383. The draft legislation was published for comment on May 29, 1998, "Civil Liability for Continuous Disclosure" (1998) 21 O.S.C.B. 3367.

${ }^{68}$ Before granting leave, the court was to be satisfied that the action was being brought in good faith and that it had a reasonable prospect of success at trial.

69 Five Year Review, "Civil Liability for Secondary Market Disclosures”, at 75-76 (Ontario: Queen's Printer, 2003) at 75.
} 
2002; however, the civil liability sections of the bill were not proclaimed into force. ${ }^{70}$ In 2003 , the Ontario Ministry of Finance tabled the Final Report of the Five Year Review Committee, which was appointed to review the Ontario Securities Act, one of the most significant being that the secondary market civil liability provisions should be brought into force. ${ }^{71}$ This report, combined with pressure to align secondary market remedies for Canadian market participants with those available in the US, provided the impetus for the Ontario Government to introduce the current regime effective 2005 . The other provinces have followed suit.

\section{Securities Class Actions against Canadian Issuers}

Although to date there are only limited cases in Canada, Canadian firms that cross-list on US exchanges have been exposed to substantially greater litigation exposure because they are subject to suits in US courts under US securities laws. We compare briefly the Canadian and US causes of action. We then offer empirical evidence on the securities suits that have been brought against Canadian issuers in both Canada and the US, and the characteristics of those suits. The pre-existing litigation exposure that US-listed Canadian firms had prior to the recent enactment of secondary market liability in Canada allows for a form of natural experiment, in terms of being able to see particular patterns in the class actions, and how the different legislative frameworks may have influenced the number and type of suits.

\section{Causes of Action and Burden of Proof}

Under the Canadian primary market civil liability provisions, a purchaser of a security offered by a prospectus during the period of distribution has a right of action against the issuer and others where the plaintiff can establish there was a misrepresentation. ${ }^{72}$ A "misrepresentation" is broadly defined to mean an untrue statement of a material fact or an omission to state a material fact that is either required to be stated or is necessary to prevent a statement that is made from being false or misleading in the circumstances in which it was made. ${ }^{73}$ This latter phrasing is aimed at capturing half-truths. ${ }^{74}$ The term "material fact" is defined as a fact that significantly

\footnotetext{
70 On May 22, 2003, the government introduced Bill 41, The Right Choices Act (Budget Measures), 2003, which contained some amendments, mostly technical, to the civil liability regime contained in Bill 198.

${ }^{71}$ Five Year Review, supra, note 69 at 75, 76. The Committee recommended: "[We] urge the Government of Ontario to move forward as soon as possible to adopt such a regime by legislative amendment."

72 OSA s. 130(1); ASA s. 203; BCSA s. 131.

${ }^{73}$ OSA s. 1(1)), ASA s. 1(ii), BCSA s. 1(1). The distinction between "material fact" and "material change" as it relates to the definition of misrepresentation is critically important.

${ }^{74}$ Kerr v. Danier Leather Inc.(2005), 77 O.R. (3d) 321 (C.A.), reversing (2004), 2004 CarswellOnt 6608 (Ont. S.C.J.), leave to appeal granted (2006), 2006 CarswellOnt 3929 (S.C.C.). It resolves common law hurdles, see for example, Hedley Byrne \& Co. v. Heller \& Partners Ltd., [1964] AC 465 (HL). Unlike the common law
} 
affects, or could reasonably be expected to significantly affect, the market price or value of the securities. ${ }^{75}$ A "material change" is defined as "a change in the business, operations or capital of the issuer that would reasonably be expected to have a significant effect on the market price or value of any of the securities of the issuer" ${ }^{76}$ There is a deemed reliance provision such that the plaintiff does not have to establish the existence of a duty of care or reliance on the misrepresentation if it was a misrepresentation at the time the security was purchased. ${ }^{77}$

US law follows a similar path, providing liability for material misstatements in the registration statement filed with the SEC, as well as the prospectus delivered to investors. Unlike Canadian legislation, however, US law does not impose liability for material changes. The accuracy of the registration statement is measured as of the time of its effective date; the prospectus is assessed as of the time that it is sent to investors. Subsequent changes to the issuer's business that render the disclosures in those documents inaccurate do not give rise to liability. ${ }^{78}$ US law also omits a reliance requirement with respect to misstatements in the registration statement or prospectus. ${ }^{79}$ In the US, both written and oral statements by the issuer and its employees are subject to liability if they contain a misrepresentation. ${ }^{80}$ Failures to disclose are actionable only if the defendant has traded on confidential information in violation of a fiduciary duty to disclose, either to the counterparty to the trade or to the source of the information. ${ }^{81}$

In Canada, there is also a right of action for those that purchased securities during the period of distribution where a misrepresentation is made in an offering memorandum. ${ }^{82}$ Where the misrepresentation has occurred in a takeover bid circular, any security holder has the right to bring an action. ${ }^{83}$ These provisions are generally consistent with the rules in the US, which provide for liability for misstatements in the registration statement for investors who can trace their shares to that statement. Misstatements in the prospectus are also actionable by those who receive the prospectus during the delivery period. US law also provides a remedy for oral misstatements made in connection with the offering, as well as written materials other than the

action, the plaintiff does not have to prove that the defendant failed to meet the standard of care or that the misrepresentation caused the loss incurred

${ }^{75}$ The wording varies slightly from one provincial jurisdiction to another.

${ }_{77}^{76}$ OSA s. 1(1), ASA s. 1 (ff ), and BCSA s. 1.

${ }_{70}$ OSA s. 130(1), ASA s. 203(1), BCSA s. 131(1).

${ }^{78}$ See Stephen J. Choi \& A.C. Pritchard, Securities Regulation: Cases and Analysis 472-476 (New York: Foundation Press, 2008).

${ }^{79}$ Securities Act $\S \S 11(a) \& 12(a)(2)$.

${ }^{80}$ Exchange Act § 10(b); Rule 10b-5.

81 United States v. O'Hagan, 521 U.S. 642 (1997).

82 OSA s. 130.1(1).

${ }^{83}$ OSA s. 131(1). 
prospectus. ${ }^{84}$ There is also a remedy for misrepresentation in forward-looking information in both jurisdictions, where the issuer has not included appropriate cautionary language.

Under Canadian secondary market civil liability provisions, no action can be commenced without leave of the court granted on motion with notice to each defendant. ${ }^{85}$ The court is to grant leave only where it is satisfied that the action is being brought in good faith and there is a reasonable possibility that the action will be resolved at trial in favour of the plaintiff. ${ }^{86}$ This provision gives a significant gate-keeping role to the court as it will have to conduct at least a preliminary examination of the impugned act or inaction in order to determine whether there is a reasonable possibility that the plaintiff will succeed at trial. There are not yet any judgments by the court in respect of leave applications; the first cases will be determinative of the ease or difficulty with which plaintiffs will be able to commence an action. ${ }^{87}$

In the US, plaintiffs are not required to seek leave of the court before filing an action, but their complaint must plead the facts relating to the fraud, including facts "giving rise to a strong inference that the defendant acted with the required state of mind," with particularity. ${ }^{88}$ Complaints that do not plead facts relating to the fraud with sufficient particularity are subject to dismissal. The challenge that this requirement poses for the plaintiff is heightened by the stay of discovery that applies while a motion to dismiss is pending. ${ }^{89}$ In practice, complaints are routinely met by a motion to dismiss, meaning that the action is effectively stayed until the court decides the motion.

Under the Canadian provisions, once the court has granted leave to commence an action, the plaintiff must promptly issue a news release disclosing that leave has been granted and must send written notice to the securities commission. ${ }^{90}$ Once commenced, the action cannot be discontinued, abandoned or settled without the approval of the court on such terms as the court thinks fit, including terms as to costs. ${ }^{91}$ In determining whether to approve the settlement of an action, the court is to consider, among other things, whether there are any other actions

\footnotetext{
84 OSA ss. 138.3(1) and (2). See generally Securities Act $\S § 11 \& 12$.

${ }^{85}$ OSA s. $138.8(1)$.

${ }^{86}$ OSA s. 138.8(1). On application for leave to commence an action, the plaintiff and each defendant are to serve and file one or more affidavits setting forth the material facts on which each intends to rely, and the maker of such an affidavit can be examined on it in accordance with the rules of court.

87 The first case seeking leave under the Ontario provisions is scheduled to be heard June 2, 2008.

${ }^{88}$ Exchange Act $\S 21 \mathrm{D}(\mathrm{b})(1) \&(2)$.

89 Exchange Act $\S 21 \mathrm{D}(\mathrm{b})(3)$.

90 OSA s. 138.9. It must also send a copy of the statement of claim or other originating document to the Commission when filed.

${ }^{91}$ OSA s. 138.10.
} 
outstanding under the same or comparable legislation in other provinces or territories in respect of the same misrepresentation or failure to make timely disclosure. ${ }^{92}$

In the US, the plaintiff must provide notice to members of the prospective class within twenty days of filing the complaint. ${ }^{93}$ Members of the class then have 90 days from the filing of the notice to make a motion to the court to be appointed lead plaintiff. ${ }^{94}$ The member of the class with the largest losses enjoys a presumption that it should be appointed as lead plaintiff, ${ }^{95}$ with the authority to select the lawyer to represent the class. ${ }^{96}$ Settlement of a US class action also requires judicial approval. Before the court can approve the settlement, notice must be given to the members of the class, setting forth the aggregate amount of the settlement, the recovery per share, and the parties' views on the amount of damages potentially recoverable. ${ }^{97}$

In respect of secondary market civil liability, Canadian securities law provides a cause of action to anyone who acquires or disposes of the issuer's securities between the time the document was released or public oral statement that contained a misrepresentation was made or there was a failure to make timely disclosure and the time the misrepresentation was publicly corrected or disclosure was made. US law is to the same effect with respect to misrepresentations, but does not require disclosure of material changes. ${ }^{98}$

Similar to the primary market provisions, there is a deemed reliance provision under the new secondary market provisions in Canada, specifically, there is no requirement for the plaintiff to demonstrate reliance on the misrepresentation or on the issuer's failure to disclose as required. ${ }^{99}$ US law retains a reliance requirement, but judicial interpretations have left that requirement somewhat attenuated. In cases of pure omission in violation of a duty to disclose, the plaintiff need only show materiality of the omitted statement. ${ }^{100}$ For affirmative statements, the Supreme Court has constructed a presumption of reliance when the misstatement was released into a capital market with active trading and a wide following among institutional investors and analysts. ${ }^{101}$

\footnotetext{
${ }^{92}$ Ibid. OSA s. 138.11 specifies that despite the Courts of Justice Act and the Class Proceedings Act, 1992, the prevailing party in an action under section 138.3 is entitled to costs determined by a court in accordance with applicable rules of civil procedure.

${ }^{93}$ Exchange Act $\S 21 \mathrm{D}(\mathrm{a})(3)(\mathrm{A})(\mathrm{i})$.

${ }^{94}$ Exchange Act $\S 21 \mathrm{D}(\mathrm{a})(3)(\mathrm{B})(\mathrm{i})$.

95 Exchange Act § $21 \mathrm{D}(\mathrm{a})(3)(\mathrm{B})(\mathrm{iii})$.

${ }^{96}$ Exchange Act § 21D(a)(3)(B)(v).

97 Exchange Act § 21D(a)(7).

98 See Gallagher v. Abbott Laboratories, 269 F.3d 806 ( $7^{\text {th }}$ Cir. 2001).

${ }^{99}$ OSA s. 138.3

${ }^{100}$ Affiliated Ute Citizens of Utah v. United States, 406 U.S. 128 (1972).

${ }^{101}$ Basic Inc. v. Levinson, 485 U.S. 224 (1988).
} 
The Canadian secondary market civil liability provisions distinguish core and non-core documents. Core documents include a prospectus, takeover-bid circular, issuer circular, directors' circular, rights offering circular, MD\&A, annual information form (AIF), interim and annual financial statements when used in relation to an outside director, an influential person who is not an officer, or a director or officer of such an influential person. ${ }^{102}$ Core documents for issuers, their officers or investment fund managers includes the same list of documents plus material change reports and any other document prescribed by regulation. ${ }^{103}$ Non-core documents require a higher burden of proof to be discharged by plaintiffs; specifically, the plaintiff must prove that the person or company knew the document or public oral statement contained a misrepresentation, or deliberately avoided acquiring the knowledge, or acted with gross misconduct in connection with release of the document or public oral statement containing the misrepresentation. ${ }^{104}$ This higher burden of proof is also required where outside directors and influential persons are being sued for failure to make timely disclosure and knew the change was material, but it is not required in relation to the issuer and its officers, or investment fund manager. ${ }^{105}$

US law makes no distinction between types of disclosure; press releases and oral statements are held to the same standard as filings made with the SEC. For all alleged misstatements, the plaintiff must plead with particularity that the defendant made the misstatement with scienter, generally held to require at least recklessness. ${ }^{106}$ For forward-looking statements, the plaintiff must plead actual knowledge of the falsity of the projection. ${ }^{107}$

Having set out the various causes of action, the next part discusses the class action proceedings filed to date under these provisions.

\section{Incidence and Characteristics of Securities Fraud Class Actions}

In Figure 1, below, we show the number of lawsuits faced by Canadian issuers. For purposes of this chart, we count lawsuits as one suit even when there are proceedings in multiple jurisdictions. So if proceedings are brought in both Ontario and Québec, these proceedings count as one suit in the "Canada" tally; if proceedings are brought in Ontario and New York, these count as one suit in the "Both" tally. The reality of these multi-jurisdictional proceedings is that the complaints allege essentially similar facts and class periods; the second filed complaints are generally copies of the initial complaint and some of the proceedings appear to have been

\footnotetext{
102 OSA s. 138.1.

103 OSA s. 138.1.

104 OSA s. 138.4(1). The plaintiff is not required to prove this in relation to an expert, OSA s. 138.4(2).

105 OSA ss. 138.4(3) and (4).

${ }^{106}$ Exchange Act § 21D(b)(2).

107 Exchange Act $\$ 21 \mathrm{E}(\mathrm{c})(1)(\mathrm{B})$.
} 
coordinated. For the cross-border proceedings, the US suit is typically filed first. Generally the actions are settled simultaneously, subject to the approval of courts in both Canada and the US.

Figure 1

Number of Securities Class Action Suits against Canadian Companies

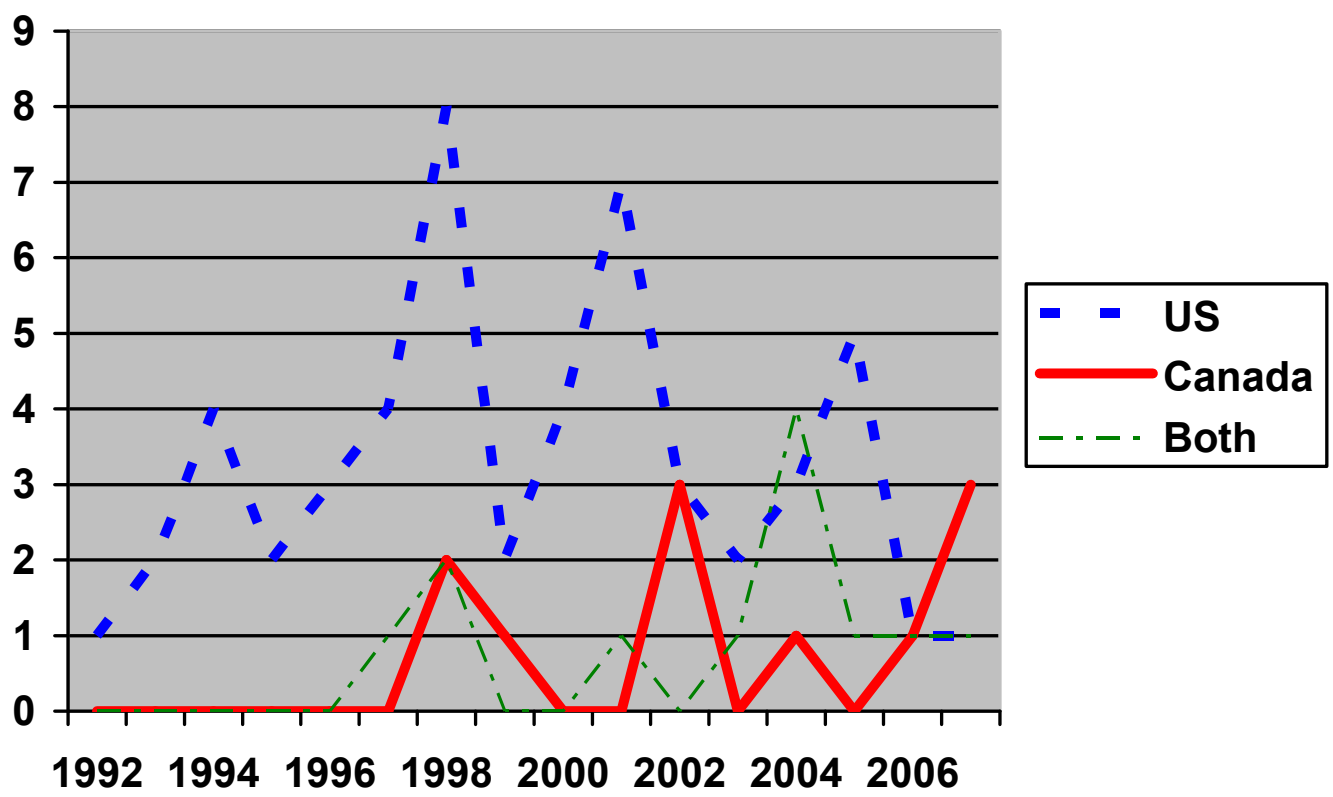

Two salient features immediately emerge from this tally of lawsuits. First, the absolute number of lawsuits remains relatively low, with no more than a handful of lawsuits in any given year. With a total of 76 lawsuits, the average is a mere five suits per year. Given the need for adequate damages to support a contingent fee recovery, the main litigation targets are likely to be issuers listed on the TSX. This translates to approximately $0.3 \%$ chance of being sued in a securities class action in a given year for the approximately 1500 TSX issuers. By way of comparison, NERA reports that the overall probability of lawsuit for all US-listed companies has ranged from $1.8 \%$ to $1.3 \%$ over that same period. ${ }^{108}$

The second salient feature is that, until quite recently, the litigation exposure faced by Canadian companies was overwhelmingly in US courts. The action is exclusively in the US until mid-1990s, with a very small number of Both and Canada only suits until the last few years, when we begin to see an uptick in Canada suits. We speculate that the class action bar in Canada is still finding its feet with respect to securities class actions; the recent adoption of the secondary market legislation greatly expands the number of available targets.

\footnotetext{
${ }^{108}$ NERA Economic Consulting, "Recent Trends in Shareholder Class Action Litigation: Filings Stay Low and Average Settlements Stay High-But Are These Trends Reversing?" (September 2007).
} 
Table 1, below, reveals that one prominent feature of the lawsuits with proceedings in Both jurisdictions is that the fraud allegations are relatively serious. Nearly $70 \%$ of the companies sued also were subjected to some sort of regulatory investigation. "Govt. Enforcement" is defined to include a government investigation, such as RCMP, provincial securities commission, SEC, or FBI, whether formal or informal, against the sued company or officers, as well as an investigation by a stock exchange. A government investigation generally is regarded as one proxy for cases of intentional fraud, and disclosure of such an investigation is a prominent signal for the plaintiffs' bar.

Another prominent signal is the announcement of a restatement of earnings or revenues by a company, which is essentially an admission that its prior financial statements included a material misrepresentation. Over half of the Both suits involve a restatement, and $39 \%$ of all actions involve accounting allegations, which are often revealed in either restatements or public disclosure to investors.

Also of note is that $57 \%$ of all actions involved forward-looking information. This figure suggests that not withstanding the existence of defences through the use of cautionary language when issuing forward looking information, there is a risk, at least at the stage of commencement of actions, of being sued for the content of the forward information, particularly for cross-listed issuers. This suggests that Canadian issuers are not any more likely to face a suit for forwardlooking information than are US issuers sued in the US. ${ }^{109}$ The incidence of forward-looking allegations remains relatively high in the US, despite the more stringent version of safe harbor in effect there, although there are very few complaints that allege forward-looking misstatements standing alone. ${ }^{110}$

\footnotetext{
${ }^{109}$ These numbers in fact appear somewhat low, given that Johnson et al. find that forward-looking allegations are included in $74 \%$ of the post-litigation reform complaints in their sample. See Johnson et al., supra note ,at Table 1.

${ }^{110}$ We discuss the differences between the Canadian and US forward looking safe harbors below. See text at infra notes -- .
} 
Table 1

Type of Suit and Allegations in US and Canadian Securities Class Actions Against Canadian Companies

\begin{tabular}{l|cccccccc}
\hline & \multicolumn{2}{|c}{$\begin{array}{c}\text { US } \\
(n=52)\end{array}$} & \multicolumn{2}{c}{$\begin{array}{c}C \boldsymbol{A} \\
(n=11)\end{array}$} & \multicolumn{2}{c}{$\begin{array}{c}\text { Both } \\
(n=13)\end{array}$} & \multicolumn{2}{c}{$\begin{array}{c}\text { Total } \\
(n=76)\end{array}$} \\
\cline { 2 - 11 } & Number & $\%$ & Number & $\%$ & Number & $\%$ & Number & $\%$ \\
\hline Govt. Enforcement & 11 & $21 \%$ & 4 & $36 \%$ & 9 & $69 \%$ & 24 & $33 \%$ \\
\hline Primary Offering & 19 & $36 \%$ & 8 & $73 \%$ & 4 & $31 \%$ & 31 & $41 \%$ \\
Secondary Market & 43 & $81 \%$ & 8 & $73 \%$ & 13 & $100 \%$ & 64 & $84 \%$ \\
\hline Forward-Looking & 30 & $57 \%$ & 4 & $36 \%$ & 9 & $69 \%$ & 43 & $57 \%$ \\
Accounting & 17 & $32 \%$ & 4 & $36 \%$ & 9 & $69 \%$ & 30 & $39 \%$ \\
Restatement & 8 & $15 \%$ & 3 & $27 \%$ & 7 & $54 \%$ & 18 & $24 \%$ \\
Laddering & 4 & $8 \%$ & 0 & $0 \%$ & 0 & $0 \%$ & 4 & $5 \%$ \\
\hline
\end{tabular}

Overall, $84 \%$ of the cases involve secondary market civil liability actions and they comprise $100 \%$ of the cases in which issuers are sued in Both jurisdictions. ${ }^{111}$ Given how recent the Canadian secondary market provisions are, this figure is likely to increase in the future because of the greater scope of available damages.

The initial cases under the Canadian secondary market provisions appear to support the supposition that restatements or admission of misrepresented information are the most likely to result in initial applications for class actions to be certified. The Imax proceeding involves claims that Imax and its officers knowingly overstated revenues for 2005, thereby artificially inflating the trading price of Imax securities. ${ }^{112}$ Imax had announced an earnings increase of $62 \%$ for the fiscal year ended on December 31, 2005. In August 2006, Imax stated that it had recognized revenue in the fourth quarter of 2005 on 10 theatre-system installations in theatres that did not open in that quarter; this disclosure was followed by a sharp drop in share price in the market. The claim alleges that the press release issued by the company, the individual certifications and the revenue statements were knowingly false and/or materially misleading. ${ }^{113}$

A class action for $\$ 110$ million general damages and $\$ 10$ million for punitive damages has been filed against CV Technologies Inc. and its CEO, two directors and the auditor, alleging misrepresentation and negligence in disclosure. ${ }^{114}$ The action arises out of the June 2007

\footnotetext{
111 "Both" signifies lawsuits brought against the same issuer in Canada and the US.

112 Statement of Claim, Marvin Neil Silver and Cliff Cohen and Imax Corporation et al, Court File \# CV-06$3257-00$, Ontario Superior Court of Justice, September 20, 2006. The value of Imax's securities declined by approximately $40 \%$ when the alleged misrepresentations were disclosed.

${ }^{113}$ The plaintiffs have filed a motion to have the case certified as a class action, scheduled to be heard during the week of June 2, 2008.

${ }^{114}$ Filed July 20, 2007 David Ainslie and Muriel Marentette v. CV Technologies Inc., Grant Thornton LLP, Jacqueline J. Shan, Gordon G. Tallman and Harry Buddle, Ontario Superior Court, Proceeding under the
} 
restatement of CV's financial statements and alleged misstated financial results based on nonGAAP revenue recognition. Another class action application, against Southwestern Resources Corp., alleges misrepresentation in assay drill results reporting and controls, after errors in reporting were publicly corrected. ${ }^{115}$ Yet another class action alleges that Celestica Inc. and certain of its officers and directors made misrepresentations or failed to make timely disclosure to investors, resulting in alleged damages to the plaintiff and other investors of $\$ 320$ million. ${ }^{116}$ The pattern illustrated by these few examples indicates that parties are pursuing cases where there is some indication in public disclosures of misconduct that was known or ought reasonably to have been known.

\section{Defendants in Securities Class Actions against Canadian Issuers}

Table 2 provides a summary of types of defendants in the class actions to date. In primary market civil liability in Canada, a civil action for misrepresentation in a prospectus can be brought against the issuer or, in the case of a sale by a control person, against the selling security holder. The action can also be brought against the underwriter, directors, any expert who consented to use of all or part of her or his opinion or report, and every person who signed the prospectus. ${ }^{117}$ Every person in a special relationship with the issuer who buys or sells securities with knowledge of a material fact or material change that has not been generally disclosed is liable to compensate the buyer or seller for damages as a result of the trade. ${ }^{118}$ Hence both the decision makers and the gatekeepers are potentially liable for misrepresentation during a primary offering. US law provides a remedy against issuers, underwriters, directors, experts, and signatories of the registration statement; control persons face liability, whether or not they are selling shares, unless the control person can show they "had no knowledge of or reasonable ground to believe in the existence of the facts" alleged to be misleading. ${ }^{119}$

\footnotetext{
Class proceedings Act, not yet certified. The class action is brought by two investors on behalf of all persons who acquired CV shares from December 11, 2006 to March 23, 2007.

${ }^{115}$ Ronald Martin v. Southwestern Resources Corp. and John Patterson, All persons other than Excluded Persons, who acquired securities of Southwestern Resource Corp. between August 31, 2005 and July 18, 2007. filed July 25, 2007. André Vézina c. Southwestern Resources Corp. et John G. Paterson Intimés, filed Que S.C. July 24, 2007; Andrew Stastny v. Southwestern Resources Corp., and John G. Paterson, filed Ontario July 20, 2007, not yet certified. In 2007, Southwestern issued a press release and disclosed that there were deficiencies in its control procedures for its Boka Gold Project and errors in reported assay due to the integrity of drill core samples being compromised. The statement of claim in suits filed in three Canadian jurisdictions allege that the defendants negligently or recklessly misrepresented the quantity of gold in its drill samples taken from the Boka Gold Project and claims $\$ 320$ million in damages on behalf of the class members.

${ }_{116}^{116}$ The action was commenced on July 30, 2007.

117 Typically, the chief executive officer and the chief financial officer of the issuer sign the prospectus, as well as promoters of the issuer.

118 OSA s. 134(1).

${ }^{119}$ Securities Act $\S 15$.
} 
Under the Canadian secondary market civil liability provisions, the class of defendants is broader than for primary market disclosure. The class includes the responsible issuer, its directors and officers, "influential persons" and, in the case of written or oral statements, experts. The definition of "influential person" with respect to a responsible issuer includes control persons, promoters, and insiders who are not directors or senior officers. ${ }^{120}$ The addition of influential persons is significant, given the traditional notion of limited liability for shareholders, and could arguably result in such shareholders engaging in a higher degree of monitoring. However, the liability for this class of potential defendants is narrow; unless the influential person released the impugned document or made the public oral statement, "knowing influence" on the responsible issuer will be required to ground an action. ${ }^{121}$

US law does not specify a class of defendants in the statute; the class of defendants has been determined by case law. The most important case on this point is Central Bank of Denver v. First Interstate Bank of Denver, in which the Supreme Court held that individuals who merely "aid and abet" a violation could not be held liable. ${ }^{122}$ According to the Court, "the statute prohibits only the making of a material misstatement (or omission) or the commission of a manipulative act." The Court recently rejected "scheme liability" for third parties that allegedly entered into sham transactions to facilitate fraud by an issuer. ${ }^{123}$ The statute does provide for liability for control persons, subject to a defence that the control person acted in good faith and did not directly or indirectly induce the violation. ${ }^{124}$

Table 2 illustrates that the number of suits naming auditors as defendants is quite low, $6 \%$, in the US category. This figure likely stems from the US Supreme Court's rejection of aiding and abetting liability. ${ }^{125}$ The less restrictive standard for secondary actors under the Canadian regimes produces a higher percentage of suits naming auditors in Canada. Underwriters are also named more frequently in lawsuits with a Canada component, likely because of the greater prevalence of offering claims in those suits. However, given how few cases there have been to date, the data are not of assistance in yet drawing broad conclusions.

Other important differences show up in the slightly higher percentage of officers sued in suits with a US component, and the higher percentage of directors appearing as defendants in suits with a Canada component. These discrepancies highlight the importance that the scienter requirement plays in Rule 10b-5 claims in the US. Lawsuits filed under that provision need to include the

\footnotetext{
${ }^{120}$ OSA s. 138.1.

121 OSA ss. $138.3(1)$ to (3).

122511 U.S. 164 (1994).

123 Stoneridge Inv. Partners, LLC. v. Scientific-Atlanta, Inc. and Motorola, Inc., - U.S. - (2008).

124 Exchange Act $\S 20(a)$.

125 Central Bank of Denver v. First Interstate Bank of Denver, 511 U.S. 164 (1994).
} 
officer to establish the corporation's scienter, while allegations of scienter against the directors are likely to be difficult to sustain, given their lack of proximity to the corporation's information flows. The number of cross-listed firms is quite high for the US and Both categories, as expected; the handful of Canadian firms sued in the US without listing their shares there involved private placements to US investors.

Table 2

Defendants in US and Canadian Securities Class Actions Against Canadian Companies

\begin{tabular}{c|cccccccc}
\hline & \multicolumn{2}{|c}{$\begin{array}{c}\text { US } \\
(\mathrm{n}=52)\end{array}$} & \multicolumn{2}{c}{$\begin{array}{c}\text { CA } \\
(\mathrm{n}=11)\end{array}$} & \multicolumn{2}{c}{$\begin{array}{c}\text { Both } \\
(\mathrm{n}=13)\end{array}$} & \multicolumn{2}{c}{$\begin{array}{c}\text { Total } \\
(\mathrm{n}=76)\end{array}$} \\
\cline { 2 - 9 } & Number & $\%$ & Number & $\%$ & Number & $\%$ & Number & $\%$ \\
\hline Company & 47 & $90 \%$ & 9 & $82 \%$ & 12 & $92 \%$ & 68 & $89 \%$ \\
Insolvent & 6 & $12 \%$ & 3 & $27 \%$ & 5 & $38 \%$ & 14 & $18 \%$ \\
Cross-listed & 51 & $96 \%$ & 2 & $18 \%$ & 12 & $92 \%$ & 65 & $86 \%$ \\
\hline Officers & 44 & $85 \%$ & 8 & $73 \%$ & 12 & $92 \%$ & 64 & $84 \%$ \\
Directors & 23 & $44 \%$ & 7 & $64 \%$ & 8 & $62 \%$ & 38 & $50 \%$ \\
Auditor & 3 & $6 \%$ & 3 & $27 \%$ & 4 & $31 \%$ & 10 & $13 \%$ \\
Underwriter & 8 & $15 \%$ & 4 & $36 \%$ & 3 & $23 \%$ & 15 & $20 \%$ \\
\hline
\end{tabular}

Only $18 \%$ of firms filed insolvency proceedings overall. The percentage in the Both category is considerably higher, which may be attributable to the relatively well-developed cross-border mechanisms for restructuring proceedings and their ability to deal with class actions suits. If the current proposed amendments to Canadian insolvency legislation come into force, there is likely to be an increased number of insolvency filings in connection with securities class action suits as claims arising out of securities law violations will be completely subordinated in any insolvency workout. $^{126}$

\section{Outcomes of Class Actions}

There are rights to rescission and to damages under both Canadian and US securities law. In Canada, there is a right of rescission under the primary market civil liability provisions. Purchasers may elect to exercise a right of rescission against a person, company or underwriter that sold them the securities, in which case they have no right of action for damages. ${ }^{127}$ There are rights to rescission for misrepresentations in an offering memorandum and takeover circular as well. ${ }^{128}$ US law affords a right of rescission against the issuer as well as the underwriter in a firm commitment offering for misrepresentations in the prospectus, as well as in written and oral

\footnotetext{
${ }^{126}$ Currently such claims are subordinated under US law, but not necessarily under Canadian law.

127 OSA s. $130(1)$.

128 OSA ss. $130.1(2), 131$.
} 
statements made in the course of the offering. Misstatements in the registration statement only allow for damages. ${ }^{129}$

There are limitations to primary market liability that are consistent in the US and Canada. In an action for damages, the defendant is not liable for any portion of the damages that the defendant proves does not represent the depreciation in value of the security as a result of the misrepresentation. ${ }^{130}$ The amount recoverable cannot exceed the price at which the securities were offered to the public. ${ }^{131}$ No underwriter is liable for more than the total public offering price represented by the portion of the distribution underwritten by the underwriter. ${ }^{132}$ The statute provides for joint and several liability; in the US, outside directors are protected by proportionate liability. ${ }^{133}$

In an action for damages for misrepresentation in an offering memorandum or takeover circular, the defendant is not liable for portions of the damages that the defendant proves do not represent the depreciation in value of the security as a result of the misrepresentation. ${ }^{134}$ Defendants are afforded a similar loss causation defence in the US for misstatements in the prospectus; $;^{135}$ plaintiffs bear the burden of proving loss causation for misrepresentations made in connection with a tender offer. ${ }^{136}$

The clearest division between Canada and the US arises on the question of damages under the secondary market provisions. Under US law, damages are potentially unlimited. By contrast, in Canada there is a cap on potential liability, which is likely to have a significant effect on the number and nature of actions brought. The liability cap limits the damages payable by a defendant issuer or an influential person that is not an individual to the greater of $\$ 1$ million or $5 \%$ of the issuer's market capitalization. ${ }^{137}$ Damages payable by a director or officer of the issuer, individual influential person or director or officer of an influential person are limited to the greater of $\$ 25,000$ or $50 \%$ of annual aggregate compensation received from the issuer or influential person and affiliates. ${ }^{138}$ The liability cap for experts is $\$ 1$ million or the revenue that the expert and its affiliates have earned from the issuer and its affiliates during the 12-month period immediately preceding the day on which the misrepresentation or the failure to make timely

\footnotetext{
129 Securities Act $\S \S 11(\mathrm{e}) \& 12(\mathrm{a})(2)$

130 See for example OSA s. 130(7); Securities Act $§ 11(\mathrm{e})$.

${ }^{131}$ OSA s. 130(8) and (9); Securities Act § 11(e).

132 OSA s. 130(6); Securities Act § 11(e).

${ }^{133}$ Securities Act $\S 11$.

134 OSA s. $130.1(3)$; s. $131(9)$;

135 Securities Act $\S 12(\mathrm{~b})$.

${ }^{136}$ See Schreiber v. Burlington Northern, Inc., 472 U.S. 1 (1985).

137 OSA s. 138.7.

138 OSA, s. 138.1 .
} 
disclosure occurred. ${ }^{139}$ Liability can be proportionately allocated in respect of each defendant's responsibility for the damages assessed. ${ }^{140}$ US law also provides for proportionate liability, although joint-and-several liability applies to knowing violations. ${ }^{141}$

The Canadian secondary market liability limits are inapplicable, except for the responsible issuer, if the plaintiff can prove the defendant authorized, permitted or acquiesced in, or influenced, the making the misrepresentation or failure to make timely disclosure while knowing it was misrepresentation or failure to make timely disclosure. ${ }^{142}$ This is a significant exception to the liability limits for individuals. It may result in actions being brought only in the clearest cases of fraud or misrepresentation, such as earnings restatements, in order for plaintiffs to avoid the liability cap. It may be that the only cases that are financially worth pursuing, given the costs of litigation, are those cases in which the cap on damages would not apply. Of course, if the issuer has a sufficiently large market capitalization, even $5 \%$ of that figure should be sufficient to justify a lawsuit.

The damages cap was intended to balance the ability of investors to seek a remedy and the desire to protect and advance capital market activity through the protection of officers and other persons. The limit on damages, absent fraud, will deter non-meritorious actions. It will also likely result in investors recovering less than the full amount of their losses, absent fraud. Even then, the liability cap for issuers means that investors are unlikely to recover full compensation in cases of significant fraud. One question is whether the liability cap has been appropriately priced, in terms of creating the appropriate mix of remedies and deterrence. Condon has suggested that the limit on damages indicates that legislators were more interested in achieving deterrence than compensation. She observes "whether the goal of deterrence will be achieved such that the possibility of being sued will concentrate the minds of management or individual influential shareholders engaged in disseminating corporate information, one issue will be whether the liability caps are pitched at a rigorous enough level to produce this effect." ${ }^{143}$ This focus on deterrence is consistent with the "pocket shifting" critique of secondary market class actions discussed above.

There is highly codified language in respect of how the court is to assess damages, including specified trading dates and how to calculate the value of damages. ${ }^{144}$ The provisions do not

\footnotetext{
${ }^{139}$ OSA, s. 138.1.

${ }^{140}$ OSA s. 138.6.

${ }^{141}$ Exchange Act $\S 21 \mathrm{D}(\mathrm{f})$.

142 OSA s. $138.7(2)$.

${ }^{143}$ Condon, supra, note 19 at 41.

144 OSA s. 138.5.
} 
require plaintiffs to crystallize those losses by selling the security in order to compute damages. ${ }^{145}$ However, the defendant is not liable for any amount that it can prove is attributable to a change in market price of the securities that is unrelated to the misrepresentation or failure to make timely disclosure. ${ }^{146}$ US law makes loss causation part of the plaintiff's burden of proof; the plaintiff must also plead loss causation in its complaint. ${ }^{147}$

Table 3 illustrates the outcomes of the lawsuits. Whereas in Figure 1 and Tables 1 and 2, we compiled suits with both Canada and US proceedings as one suit, in Table 3 we separately break out the resolution of those cross-border lawsuits. Some cases were dismissed on one side, but were settled or remain active on the other side of the border. The settlements are reported on a consolidated basis, however, as most of the settlements involve a universal resolution. The settlement figures are reported in US dollars.

Table 3

Outcome of Securities Class Actions Against Canadian Companies

\begin{tabular}{c|cccccccc}
\hline & \multicolumn{2}{|c}{$\begin{array}{c}\text { US } \\
(\mathrm{n}=52)\end{array}$} & \multicolumn{2}{c}{$\begin{array}{c}\text { CA } \\
(\mathrm{n}=11)\end{array}$} & \multicolumn{2}{c}{$\begin{array}{c}\text { Both } \\
(\mathrm{n}=26)\end{array}$} & \multicolumn{2}{c}{$\begin{array}{c}\text { Total } \\
(\mathrm{n}=89)\end{array}$} \\
\cline { 2 - 9 } & Number & $\%$ & Number & $\%$ & Number & $\%$ & Number & $\%$ \\
\hline Dismiss & 10 & $19 \%$ & 2 & $18 \%$ & 3 & $12 \%$ & 15 & $17 \%$ \\
Settled/Judgment & 33 & $63 \%$ & 3 & $27 \%$ & 15 & $58 \%$ & 51 & $57 \%$ \\
Active & 9 & $17 \%$ & 6 & $55 \%$ & 8 & $31 \%$ & 23 & $26 \%$ \\
\hline Mean Settlement & $9,592,991$ & $10,884,325$ & $284,303,401$ & $73,087,034$ \\
Excluding Nortel & & & & & $48,812,857$ & $17,117,668$ \\
Median Settlement & $3,750,000$ & $2,040,500$ & $75,000,000$ & $5,350,000$ \\
\hline
\end{tabular}

Settlement amounts in US dollars. "Both" category aggregates US and Canadian settlements.

The dismissal rate of $17 \%$ on its face appears to be somewhat low, given that the overall dismissal rate in the US is around 39\% for cases filed between 2001 and $2005 .{ }^{148}$ It is premature, however, to conclude that Canada is a more plaintiff friendly jurisdiction as the dismissal rate is likely depressed by the significant percentage of cases that remain active. Undoubtedly, more cases will fall by the wayside. The damages limitation and potential cost consequences, however, may mean that plaintiffs are particularly careful in selecting their cases in Canada, which may lead to a generally lower dismissal rate.

\footnotetext{
145 OSA s. $138.5(1)$

146 OSA s. $138.5(3)$.

147 Dura Pharmaceuticals, Inc. v. Broudo, 544 U.S. 336 (2005).

${ }^{148}$ NERA Economic Consulting, Recent Trends in Shareholder Class Action Litigation: Filings Stay Low and Average Settlements Stay High-But Are These Trends Reversing? (September 2007).
} 
The settlement amounts reported in Table 3 are striking, with a mean of $\$ 73$ million overall and $\$ 284$ million for suits in the Both category. These figures are inflated, however, by two outlier settlements involving Nortel of greater that $\$ 1$ billion USD, both of which rank among the top 10 ever in the US. ${ }^{149}$ The valuation of these settlements is open to question, however, as the bulk of these settlements consists of newly issued Nortel shares. The effect of this issuance is that current Nortel shareholders saw their stockholdings diluted to compensate past Nortel shareholders as well as some current Nortel shareholders. The "pocket shifting" element of this exercise is transparent. Nonetheless, the mean and median for the Both category is quite high, even with the Nortel settlements excluded. Undoubtedly, a portion of this amount can be explained by the seriousness of the allegations documented in Table 1; stronger claims should be expected to settle for larger amounts.

The existence of suits on both sides of the border also provides plaintiffs with a strategic advantage in that the Canadian lawsuit is not subject to the discovery stay applied in US courts before motions to dismiss are determined, which may give US plaintiffs access to evidence that they would not otherwise have, if plaintiffs' attorneys coordinate their efforts. The issue of how Canadian courts will treat this difference was recently litigated in Ontario in the context of a motion to compel answers to questions refused during cross-examination on a pending certification motion in the first proceeding under the secondary market civil liability provisions. ${ }^{150}$ The respondents had argued that the court's gatekeeping role under the new civil liability provisions should result in the court imposing a higher threshold for examination than the usual test of whether the information to be elicited has a "semblance of relevance" to issues in the action. The Court held that each prospective defendant must come forward with its defences, with evidence in support; and that the merits of the claim are clearly relevant to the test for leave. Based on the evidence adduced and tested, the plaintiffs must establish good faith and that the action has a reasonable possibility of success at trial. ${ }^{151}$ The Court held that while the examination was not a discovery process, the court will take a careful look at what facts are potentially relevant and material to the statutory claim and defences, as presented in the draft pleading and in the respondents' affidavits.

Part of the rationale for the discovery stay in the US is to discourage issuers from settling frivolous actions to avoid the cost of litigation before the motion to dismiss is resolved. The Canadian approach essentially allows limited discovery, in order that the parties understand the basis of the counter-party's claim or defence, and the court has the information required to determine the leave application.

\footnotetext{
${ }^{149}$ NERA Economic Consulting, ibid.

${ }^{150}$ Silver v. Imax Corp., [2008] O.J. No. 1844 (Ont. S.C.J.).

151 Ibid. at para. 18.
} 
Another factor, however, may be in play as well; such lawsuits may be more costly to settle because of their jurisdictional complexity and a greater number of parties at the table wanting to be paid. Moreover, defendants face daunting costs in continuing with the litigation because of the expense of paying counsel in both Canada and the US, giving an additional incentive to resolve the litigation. Defendants in these cases presumably want universal peace. They appear to be generally successful in obtaining it, but at a price. Another factor is the role of the insurer and its interest in containing litigation costs, discussed in Part IV below.

Once the outlier Nortel settlements are excluded, the overall mean settlement drops to slightly more than $\$ 17$ million. This figure is consistent with the averages for suits in the US; NERA reports an average settlement of $\$ 11.5$ million from 1996-2001 and \$23.2 million from 2002 to $2007 .{ }^{152}$ The overall median reported of $\$ 5.35$ million is also consistent with US experience; NERA reports median settlements in the US of $\$ 4.7$ million in US from 1996-2001 and $\$ 6.4$ million from 2002 to 2007 . This relatively low median figure has two implications; first, most suits are settling for a small percentage of investor losses; and second, half of the suits are settling for essentially nuisance value. If a suit has gotten past a motion to dismiss, it is unlikely that it could be defended for less than $\$ 5$ million dollars.

An analysis of the average time between filing and settlement of class actions reveals slight differences only. For class actions filed in the US, the average was 1,182 days; for cases filed in Canada, 1,401 days; and for cases filed in Both jurisdictions, it was 1,371 days on average between filing and settlement. In all cases, the length of time that the action is pending creates considerable uncertainty for the issuer, officers and others in terms of their potential liability. Although the complexity of trying to settle cases in both jurisdictions at the same time would arguably add time for Both, the average time was more than the US, but less than in Canada.

Canadian cases may take longer because there is little caselaw that serves as a benchmark in settling cases. In the only Canadian judgment that has rendered a final decision on forward looking information in primary markets, the Supreme Court of Canada in Kerr v. Danier Leather Inc. held that the Ontario Securities Act supplants the "buyer beware" mind set of the common law with compelled disclosure of relevant information. At the same time, the statute recognizes the burden it places on issuers and in Part XV sets the limits on what is required to be disclosed. ${ }^{153}$ The Court held that when a prospectus is accurate at the time of filing, the Act limits the obligation of post-filing disclosure to notice of a "material change", which the Act defines as a change in the business, operations or capital of the issuer that would reasonably be expected to

\footnotetext{
152 NERA Economic Consulting, supra, note $x$.

153 Ibid. at para. 32.
} 
have a significant effect on the market price or value of any of the securities of the issuer. Hence the Court held that "an issuer has no similar express obligation to amend a prospectus or to publicize and file a report for the modification of material facts occurring after a receipt for a prospectus is obtained. That is where the legislature has drawn the line". ${ }^{154}$ Hence, the Court held that the distinction between material change and material fact is deliberate and policy-based. ${ }^{155}$ The Supreme Court held that poor intra-quarterly results may reflect a material change in business operations, for example, where a company has restructured its operations it may experience poor intra-quarterly results because of this restructuring, but it is the restructuring and not the results themselves that would amount to a material change and thus trigger the disclosure obligation. The Supreme Court disagreed with the Court of Appeal in one significant aspect of the case; while forecasting is a matter of business judgment, disclosure is a matter of legal obligation. ${ }^{156}$ The Court held that the disclosure requirements under the Act are not to be subordinated to the exercise of business judgment. ${ }^{157}$

In the US, the Supreme Court has explicitly rejected any role for business judgment under the antifraud provisions. In Basic Inc. v. Levinson, the Court rejected the argument that a company in the midst of merger negotiations was justified in denying the existence of those negotiations because premature disclosure would jeopardize the potential merger. ${ }^{158}$ The Court deemed such strategic concerns "irrelevant to an assessment whether their existence is significant to the trading decision of a reasonable investor". ${ }^{159}$ Hence we see an aligning of Canadian and US jurisprudence in respect of the relationship between disclosure and business judgment.

The Canadian statutory civil liability provisions set out defences, including plaintiff knowledge of the misrepresentation; that the misrepresentation did not cause the loss; and a due diligence defence where the defendant conducted a reasonable investigation to provide reasonable grounds for a belief that there was no misrepresentation and that he or she did not believe that

\footnotetext{
154 Ibid.

155 Ibid, at para. 38.

156 Ibid., paras. 49, 51. It also held that the forecast did carry an implied representation of objective reasonableness rooted in the language of the prospectus, but this implied representation extended only until the prospectus was filed

$157 \mathrm{Ibid}$. at paras. 54, 55. Subsequent to this judgment, the Ontario Securities Commission in AiT Advanced Information Technologies Corp. (2008), 31 OSCB 712, held in the context of merger discussions that, in appropriate circumstances, a material change can occur in advance of the execution of a definitive binding agreement, and therefore, the determination of material change is not a "bright-line" test. The assessment of whether a material change has occurred, particularly in the context of an arm's length negotiated transaction, will depend on the specific facts and circumstances of each case; there must be sufficient evidence by which the board could have concluded that there was a sufficient commitment from the parties to proceed and a substantial likelihood that the transaction would be completed, before the disclosure obligation arises. This decision indicates that some deference will be accorded to business judgment.

${ }^{158}$ Basic Inc. v. Levinson, 485 U.S. 224 (1988).

159 Ibid.
} 
there was misrepresentation. ${ }^{160}$ The standard of reasonableness is that required of a prudent person in the circumstances of the particular case. ${ }^{161}$ The defendant is also not liable for any part of a prospectus based on a report or opinion of an expert where the defendant had no reasonable grounds to believe and did not believe that there had been a misrepresentation. ${ }^{162}$ Another defence is that the defendant either did not consent to the filing of the prospectus or withdrew her or his consent prior to the purchase of the securities by the purchaser and gave reasonable general notice of and reasons for such withdrawal. ${ }^{163}$ These defences are also afforded by US law. ${ }^{164}$

Experts are held to a duty of reasonable investigation with respect to that part of the prospectus prepared on their authority as experts. ${ }^{165}$ Although the distinction between experts and nonexperts is significant in due diligence defences, these terms are not defined in Canadian law. The portion of the prospectus prepared by an expert appears to include the audited financial statements as well as those parts of the issuer's description of activities prepared by engineers, geologists and other experts. ${ }^{166}$ US law specifies that this category includes "every accountant, engineer, or appraiser, or any person whose profession gives authority to a statement made by him" ${ }^{167}$ There is no case directly on point in Canada, however, in the context of administrative sanctions under the Ontario Securities Act (OSA), the OSC panel in YBM Magnex International Inc. discussed the due diligence obligations of directors, officers, underwriters, and experts associated with an issue of securities a time when the issuer was being investigated by the US Attorney's office for potential illegal activity. ${ }^{168}$

The issuer of the securities or selling security holder is strictly liable for misrepresentations in a prospectus, as it is not entitled to claim the defence of due diligence, the defence of not having consented to the prospectus, or the defence that the misrepresentation was not made by it. ${ }^{169}$ Under US law, the issuer is strictly liable for misrepresentations in the registration statement. ${ }^{170}$

160 OSA ss. $130(2)$ to (7)); ASA ss. 203(4) to (9); BCSA ss. 131(4) to (10).

161 See for example, OSA s. 132.

162 See for example, OSA s. 130(3).

163 OSA s. 130(3).

164 Securities Act $\S 11(b)$.

165 See for example, OSA s. 130(4).

166 This issue is discussed in detail in the US decision of Escott v. BarChris Construction Corp., $283 \mathrm{~F}$ Supp. 643 (1968) in the context of s. 11 US civil liability for a false registration statement, and while this decision is generally relied on in Canada, there do not appear to be any decided Canadian judgments on this question.

167 Securities Act $\S 11(a)(4)$.

168 Dealing with a matter under OSA s. 127. Re YBM Magnex International Inc. (2003) 26 OSCB 5285.

169 OSA ss. $130(3)$ to (5).

170 Securities Act $\S 11(\mathrm{~b})$. 
Similar provisions set out liability for misrepresentation in an offering memorandum under Canadian law, ${ }^{171}$ except the issuer is not liable where it is not receiving any proceeds from the distribution and the misrepresentation was not based on information provided by the issuer. ${ }^{172}$ The exception is where the misrepresentation was based on information previously disclosed by the issuer and the misrepresentation was not corrected prior to completion of the distribution of the securities. ${ }^{173}$ Under US law, issuers are liable for misrepresentations in the prospectus only for primary offerings, and all defendants are entitled to a defence of reasonable care for misstatements in a prospectus. ${ }^{174}$

In Canada, there are similar defences to misrepresentation in a takeover circular against directors of the offeror, issuer or persons that signed a certificate in the circular or notice. ${ }^{175}$ Here too, the standard of reasonable investigation or reasonable grounds for belief under the defence is that required of a prudent person in the circumstances of the particular case. ${ }^{176}$ Under US law, the plaintiff must prove that the defendant acted recklessly or knowingly in making misrepresentations in connection with a tender offer. ${ }^{177}$

In Canada, a person or company is not liable in an action for a misrepresentation in forwardlooking information under the prospectus, offering memorandum or circular provisions if the person or company can establish that the document containing the information contained reasonable cautionary language identifying it as forward-looking; identified material factors that could cause actual results to differ materially; included a statement of material factors or assumptions that were applied in making a forecast or projection; and the person or company had a reasonable basis for drawing the conclusions or making the forecast. ${ }^{178}$ This defence, however, does not relieve a person or company of liability in respect of forward-looking information in a financial statement or in a document released in connection with an initial public offering. ${ }^{179}$

\footnotetext{
171 OSA, s. 130, however the section only applies with respect to an offering memorandum that has been furnished to a prospective purchaser in connection with a distribution of a security under an exemption from s. 53 of the OSA that is specified in the regulations, OSA, s. 130.1 (8).

172 See, for example, OSA, s. 130.1.

173 See, for example, OSA, s. 130.1.

174 Securities Act Rule 159A and Securities Act § 12(a)(2).

175 See, for example, OSA, s. 131. This includes deemed take-over bid circulars or issuer bid circulars, essentially disclosure documents required to be filed where an issuer-bid or takeover bid is exempted from circular provisions of the statute, see for example OSA s. 131(10).

176 See, for example, OSA, S. 132. There are also provisions in respect of liability for persons in a special relationship with the reporting issuer where a material fact or change is undisclosed and for tipping, as well as provisions dealing specifically with mutual funds; OSA ss. 134.

177 See Connecticut National Bank v. Fluor Corp., 808 F.2d 957 (2d Cir. 1987).

178 OSA s. 132.1.

179 See, for example, OSA s. 132.1.
} 
The US safe harbour does not require a reasonable basis for forward-looking statements if they are accompanied by meaningful cautionary language. ${ }^{180}$ Even if there is no cautionary language, the defendant will not be liable unless the plaintiff proves that the forecast or projection was made with actual knowledge of its falsity. ${ }^{181}$ Financial statements are excluded from the protection of the safe harbour, as are statements made in connection with a tender offer or an initial public offering. ${ }^{182}$

Pursuant to Canadian securities law, a person in a special relationship with the issuer who buys or sells securities with knowledge of a material fact or material change that has not been generally disclosed, has a defence to liability where the person proves that he or she reasonably believed that the material fact or change had generally been disclosed or it was known or ought reasonably to have been known by the seller or purchaser. ${ }^{183}$ In the US, such a claim would have to be brought under Rule 10b-5 of the Exchange Act, which requires the plaintiff to plead with particularity and prove scienter. ${ }^{184}$

Defences to civil liability under the secondary market provisions include a due diligence defence, a defence that the plaintiff knew of the misrepresentation; ${ }^{185}$ a reliance on experts, ${ }^{186}$ or the making of confidential disclosure to the regulator if there was a reasonable basis. ${ }^{187}$ In the US, the latter two defences are not available, but the first two questions are part of the plaintiff's case, in the form of the scienter requirement and the materiality requirement. Unless the defendant has acted recklessly, he or she will not be liable. Moreover, if the true state of affairs is known to market participants, the alleged misstatement will be deemed immaterial under the "truth on the market" defence. ${ }^{188}$

The most relevant defence under Canadian law may be the due diligence defence, whereby an outside director or influential person has conducted or caused to be conducted a reasonable investigation and has no reasonable ground to believe there is a misrepresentation. ${ }^{189}$ The due diligence defence thus differs from the primary market provisions, in that the onus is on the defendant to establish the due diligence. The statutory language enumerates factors that should

180 Securities Act $\S 27 A(c)(A)$.

181 Securities Act $\S 27 A(c)(1)(B)$.

182 Securities Act $\S 27 A(b)(2)$.

183 OSA s. 134(1).

184 Exchange Act $\S 21 \mathrm{D}(\mathrm{b})(2)$.

185 OSA s. 138.4(5). The burden of proof is on the defendant.

186 OSA s. 138.4(11). Expert is defined as a person or company whose profession gives authority to a statement made in a professional capacity, including but not limited to an accountant, actuary, appraiser, auditor, engineer, financial analyst, geologist or lawyer, and excluding an entity that is an approved rating organization for purposes of $\mathrm{NI} 44-101$; OSA s. 138.1.

${ }_{187}$ OSA s. $138.4(8)$.

188 See, e.g., Wielgos v. Commonwealth Edison Co., 892 F.2d 509 (7 $7^{\text {th }}$ Cir. 1989).

189 OSA s. $138.4(6)$. 
be considered by a court in determining whether the defendants undertook a reasonable investigation or alternatively were guilty of gross misconduct. ${ }^{190}$ The court is to consider all relevant circumstances, including:

- the nature of the responsible issuer;

- the knowledge, experience and function of the person or company and any office held;

- the presence or absence of another relationship with the responsible issuer, if the person was a director;

- the existence and nature of any system designed to ensure that the responsible issuer meets its continuous disclosure obligations;

- the reasonableness of reliance by the person or company on the responsible issuer's disclosure compliance system and on employees whose duties would in the ordinary course have given them knowledge of the relevant facts;

- the period within which disclosure was required to be made under the applicable law;

- in respect of a report, statement or opinion of an expert, any professional standards applicable to the expert;

- the extent to which the person or company knew, or should reasonably have known, the content and medium of dissemination of the document or public oral statement;

- in the case of a misrepresentation, the role and responsibility of the person or company in the preparation and release of the document or public oral statement; and

- in the case of a failure to make timely disclosure, the role and responsibility of the person or company involved in a decision not to disclose the material change. ${ }^{191}$

A significant factor is the existence of any system designed to ensure that the responsible issuer meets its continuous disclosure obligations. Issuers are therefore likely to establish written disclosure policies to ensure adequate controls and monitoring of continuous disclosure and for determinations as to when a change is material. This factor aligns with requirements in a number of Canadian jurisdictions whereby the CEO, CFO, must personally certify that, among other things, that the issuer's annual filings and interim filings do not contain any misrepresentations; that the financial statements and other financial information in the annual filings and interim filings fairly present the financial condition, results of operations and cash flows of the issuer; and that they have designed disclosure controls and procedures or caused them to be designed under

\footnotetext{
${ }^{190}$ OSA s. $138.4(7)$

191 Ibid.
} 
their supervision. ${ }^{192}$ The US does not require continuous disclosure, although it does require certification of periodic filings by CEO and CFO. ${ }^{193}$

Under the OSA, a defendant is not liable for a misrepresentation in forward-looking information if the defendant proves that the document or oral statement containing the information included, "proximate to" the information: reasonable cautionary language identifying the information as forward-looking and identifying material factors that could cause results to diverge materially. In addition, the defendant must prove that it had a reasonable basis for the conclusion, forecast or projection. ${ }^{194}$ If the forward-looking information is contained in an oral statement, the cautions must be stated orally, in general terms, along with a reference to an available document that discloses the factors and assumptions. ${ }^{195}$ Forward-looking information includes, but is not limited to, future-oriented financial information with respect to prospective results of operations, financial position and/or cash flows that is presented as either a forecast or a projection. ${ }^{196}$ In the US, meaningful cautionary language will insulate forward-looking statements from liability; there is no additional requirement that the forecast have a reasonable basis. ${ }^{197}$ The current Canadian provision roughly corresponds to the state of US law before the passage of the PSLRA. US law is generally to the same effect as Canadian law in respect of oral forward looking statements. ${ }^{198}$

A further defence under the Canadian secondary market civil liability provisions is that a person or company is not liable for a misrepresentation in a document, other than a document required to be filed with the Commission, if the person or company proves that, at the time of release of the document, it did not know and had no reasonable grounds to believe that the document would be released. ${ }^{199}$ A person or issuer is also not liable for derivative information, drawn from information filed by another person or company, other than the responsible issuer, with a securities regulatory authority in Canada or a stock exchange and not corrected before the release of the document or the public oral statement and where the person had no reasonable

\footnotetext{
192 National Instrument 52-109 Certification of Disclosure in Issuers' Annual and Interim Filings; NI 51-102 Continuous Disclosure Obligations Related Amendments, http://www.osc.gov.on.ca/Regulation/Rulemaking/Current/Part5/csa 20071123 52-319 status-52-109.jsp. ${ }^{193}$ Exchange Act Rule 13a-14.

194 OSA s. 138.4(9).

195 OSA s. 138.4(9.1).

196 Securities Act, s. 1(1). "Forward-looking information" means "disclosure regarding possible events, conditions or results of operations that is based on assumptions about future economic conditions and courses of action and includes future oriented financial information with respect to prospective results of operations, financial position or cash flows that is presented either as a forecast or a projection". The OSC gives earnings guidance is an example of forward-looking information, as well as MD\&A that may contain forward-looking information. For purposes of the defence, a document filed with the Commission or otherwise generally disclosed is deemed to be "readily available", s. 138.4(9.2) of the OSA.

197 Exchange Act $§ 21 \mathrm{E}(\mathrm{c})(\mathrm{A})(\mathrm{i})$.

198 Exchange Act $\S 21 \mathrm{E}(\mathrm{c})(2) \&(3)$.

199 OSA s. 138.4(13).
} 
grounds to believe that the document or public oral statement contained a misrepresentation. ${ }^{200}$ There is also no liability where the misrepresentation or failure to make timely disclosure was made without the knowledge or consent of the person and, if, after the person or company became aware before it was corrected, the person or company promptly notified the board of directors of the responsible issuer. ${ }^{201}$ US law does not contain specific provisions on this point; the question would be addressed by the scienter requirement.

The combination of the leave provisions, the liability cap and the defences available make it likely that actions will be sought under the Canadian secondary market provisions only for the most egregious conduct or where the conduct can be easily established, such as following an earnings restatement with a significant market price drop immediately following the restatement. However, since liability can be assessed against individual defendants, the statutory framework is designed to contribute to the deterrence objective of private remedies. Since the liability limits are inapplicable if intentional misconduct can be proven, plaintiffs are likely to allege fraud in order to pressure defendants to settle in order to avoid unlimited exposure to damages.

With respect to the calculation of losses in order to compute damages, the provisions do not require plaintiffs to crystallize those losses by selling the security. A 2005 US Supreme Court decision on this issue has adopted a stricter approach to the requirement for plaintiffs in US cases to prove a causal connection between the alleged misrepresentation and the economic loss suffered. ${ }^{202}$ Plaintiffs must not only show that there was a misrepresentation that affected the market price, but that there was subsequent correction to the price when the truth was revealed. Moreover, facts supporting loss causation must be plead in the plaintiff's complaint. The US Supreme Court observed that it was seeking to achieve the policy goal of avoiding "abusive" litigation. In Canada the onus is on the defendant to prove that losses were unrelated to the misrepresentation. Whether styled as an element of the claim or an affirmative defence, the question of loss causation is likely to trigger a contest between experts on the issue of what caused the issuer's stock price to decline.

Summing up, the overall litigation exposure for Canadian companies remains relatively low when compared to their counterparts in the US. Not surprisingly, Canadian issuers that have listed their shares in the US face the greatest litigation exposure, particularly the possibility of having to defend lawsuits in both jurisdictions. Such lawsuits are substantially more costly to resolve. The

\footnotetext{
200 OSA s. $138.4(14)$

201 OSA s. 138.4(15). If no correction of the misrepresentation or no subsequent disclosure of the material change is made by the responsible issuer within two business days after the notification, the person or company, unless prohibited by law or by professional confidentiality rules, must have promptly and in writing notified the Commission of the misrepresentation or failure to make timely disclosure.

${ }^{202}$ Dura Pharmaceuticals, Inc. v. Broudo, 544 U.S. 336 (2005).
} 
introduction of secondary market legislation makes this risk considerably more acute. The marginal deterrence provided by the threat of additional litigation in Canada for issuers that are already at risk of litigation in the US is likely rather limited.

\section{The Effect of Secondary Market Civil Liability on D\&O Insurance}

This part briefly explores the link between director and officer (D\&O) insurance and class action suits and their settlement. D\&O insurance policies typically provide protection against losses, defined as any amounts the directors and officers are obligated to pay from claims made against them for wrongful acts, including judgment, settlement amounts and litigation costs. ${ }^{203}$ Wrongful acts are defined in a number of insurance policies as including errors, misstatements or misleading statements or acts of omission or breach of duty, with some specified exemptions, such as liability arising from corporate pension and benefit plans. ${ }^{204}$ Hence, where insurance policies cover potential liability under securities law, insurers are likely to influence the outcome of proceedings. Moreover, there is likely to be a correlation between the new secondary market civil liability provisions and both the cost and coverage of D\&O insurance.

The premia that insurers charge for D\&O policies may be a barometer of the expected cost of securities litigation. If the expected cost of securities litigation goes up, D\&O premia should increase as well. A natural experiment arises from the fact that for Canadian issuers listed in the US, the enactment of secondary market liability in Canada was unlikely to have increased the expected cost of securities litigation for those firms. We hypothesized that only Canadian firms listed exclusively in Canada were likely to have been charged more for D\&O insurance in response to new secondary market legislation. To test this hypothesis, we compared the D\&O rates for Canadian companies listed in the US with those listed in only in Canada. We speculated that the impact of the legislation will be most pronounced for firms listed only in Canada because Canadian firms listed on US exchanges already had substantial risk of litigation.

To explore this question, we collected D\&O premia for 2004, 2005, and 2006 for the 250 largest firms on the Toronto Stock Exchange, as measured by market capitalization. We focused on the largest firms because prior research on US firms has shown that the size of a company is an

\footnotetext{
${ }^{203}$ Coronation Ins. Co. Ltd. v. Clearly Canadian Beverage Corp., [1999] B.C.C.A. 11 at para. 2. Although the Ontario Securities Act s. 128(3) and other statutes provide for restitution orders, they have been rarely used to date in Canada, although they are frequently used in the US.

${ }^{204}$ Mary Jane Stitt, "Insurance Claims for III Gotten Gains: The Insurability of Restitutionary Damages", 2006, on file with author, at 3; Lazar Sarna, ed. Directors and Officers: A Canadian Legal manual, (Montréal: Jewel Publications, 2006) at 4-3.
} 
important determinant of suit. ${ }^{205}$ Smaller firms are unlikely to be sued because the potential damages available are unlikely to support an adequate fee recovery. Data on market capitalization were obtained from the Toronto Stock Exchange and data on D\&O policies and premia for the companies were obtained from the management's information circular on SEDAR. We were able to obtain D\&O data for at least two consecutive years for 153 firms. ${ }^{206}$ All figures have been converted to Canadian dollars.

Table 4 summarizes the characteristics of the sample firms and their D\&O policies. The firms listed in the US are substantially larger, with a mean (median) market capitalization of $\$ 11.5$ billion ( $\$ 4.1$ billion), compared with $\$ 3.4$ billion ( $\$ 1.6$ billion) for the firms listed only in Canada. Not surprisingly, the US listed firms have correspondingly higher policy limits, although the discrepancy is not as great as it is for market capitalization, with the mean US listed firm carrying slightly over $\$ 110$ million ( $\sim \$ 100$ million) in coverage over each of the three years in our sample period, while the mean for the Canadian only firms is between $\$ 65$ and $\$ 78$ million (median between $\$ 35$ and $\$ 47$ million). The policy limit and net coverage data reveal an important trend: firms listed only in Canada faced a substantial reduction in policy limits between 2004 and 2005 ( -\$8.5 million), while the US listed firms stayed relatively stable $(\sim-\$ 0.6$ million). This finding suggests that insurers negotiated more conservative policy limits in response to the new legislation. This relation holds after adjusting for deductibles (Net Coverage).

${ }^{205}$ Marilyn F. Johnson, Karen K. Nelson, \& A.C. Pritchard, "Do the Merits Matter More? The Impact of the Private Securities Litigation Reform Act" (2007) 23 J. Law, Econ., \& Org. 625.

${ }^{206}$ The sample size is slightly smaller for 2006 - 138 firms - as a small number of firms were delisted after being acquired. 
Table 4

Directors' \& Officers' Insurance Policy Limits and Deductibles

\begin{tabular}{c|llllll}
\hline & \multicolumn{2}{|c}{$\begin{array}{c}\text { Total } \\
n=153\end{array}$} & \multicolumn{2}{c}{ US Listed } & \multicolumn{2}{c}{$\begin{array}{c}\text { Canada Only } \\
n=71\end{array}$} \\
& Mean & Median & Mean & Median & Mean & Median \\
\hline $\begin{array}{l}\text { Market Capitalization } \\
\text { (2005) }\end{array}$ & $7,140.57$ & $2,181.46$ & $11,549.01$ & $4,050.86$ & $3,377.26$ & $1,608.12$ \\
Policy Limit & & & & & & \\
2004 & 93.23 & 50.00 & 111.39 & 95.18 & 77.97 & 35.00 \\
2005 & 87.89 & 50.00 & 110.81 & 100.00 & 68.63 & 37.50 \\
$\Delta 2005$ & -4.82 & 0.00 & -0.57 & 0.00 & -8.49 & 0.00 \\
2006 & 88.00 & 50.00 & 113.66 & 100.00 & 65.01 & 46.66 \\
$\Delta 2006$ & 3.63 & 0.02 & 2.68 & 0.03 & 4.48 & 0.01 \\
Deductible & & & & & & \\
2004 & 1.81 & 0.60 & 2.84 & 1.00 & 0.92 & 0.30 \\
2005 & 1.90 & 0.58 & 3.00 & 1.00 & 0.95 & 0.29 \\
2006 & 2.09 & 0.58 & 3.28 & 1.00 & 0.96 & 0.29 \\
Net Coverage & & & & & & \\
2004 & 91.53 & 49.50 & 108.72 & 92.38 & 76.67 & 34.50 \\
2005 & 86.12 & 49.75 & 107.99 & 95.00 & 67.45 & 36.61 \\
$\Delta 2005$ & -4.90 & 0.00 & -0.72 & -0.58 & -8.52 & 0.00 \\
2006 & 85.93 & 49.93 & 110.23 & 99.00 & 64.17 & 46.36 \\
$\Delta 2006$ & 3.39 & 0.02 & 2.11 & 0.02 & 4.53 & 0.01 \\
\hline
\end{tabular}

All figures in millions of Canadian dollars.

Table 5, Panel A presents descriptive statistics on the premia charged for D\&O insurance. Panel A shows an overall picture of easing in D\&O premia, with the average premia paid for declining over the sample period for the overall sample. For issuers listed only in Canada, however, the average premia was unchanged from 2004 to 2005, at both the mean and the median. In 2006, the premia paid by the Canadian-listed issuers declines at the mean, but not as sharply as the reduction enjoyed by the US-listed issuers. This overall stability for the Canadian only issuers appears to be driven by steep declines for a handful of the issuers, with the medians largely unchanged from year to year. 
Table 5

Directors' \& Officers' Insurance Policy Premia

Panel A: Premia

\begin{tabular}{ccccccr}
\hline & \multicolumn{2}{c}{$\begin{array}{c}\text { Total } \\
\mathrm{n}=153\end{array}$} & \multicolumn{2}{c}{ US Listed } & \multicolumn{2}{c}{ Canada Only } \\
$\mathrm{n}=71$ & \multicolumn{2}{c}{$\mathrm{n=82}$} \\
\hline & Mean & Median & Mean & Median & Mean & Median \\
$\mathbf{2 0 0 4}$ & 1.08 & 0.53 & 1.75 & 1.00 & 0.49 & 0.26 \\
$\mathbf{2 0 0 5}$ & 1.06 & 0.57 & 1.73 & 1.01 & 0.49 & 0.27 \\
$\Delta \mathbf{2 0 0 5}$ & -0.01 & 0.00 & -0.03 & -0.03 & 0.00 & 0.00 \\
$\mathbf{2 0 0 6}$ & 1.02 & 0.57 & 1.64 & 1.21 & 0.44 & 0.27 \\
$\Delta \mathbf{2 0 0 6}$ & -0.07 & 0.00 & -0.08 & 0.00 & -0.05 & 0.00 \\
\hline
\end{tabular}

All figures in millions of Canadian dollars.

Panel B: Ratio of Coverage to Premia

\begin{tabular}{ccccccc}
\hline & \multicolumn{2}{c}{ Total } & \multicolumn{2}{c}{$\begin{array}{c}\text { US Listed } \\
\mathrm{n}=153\end{array}$} & \multicolumn{2}{c}{$\begin{array}{c}\text { Canada Only } \\
\mathrm{n}=71\end{array}$} \\
\hline & Mean & Median & Mean & Median & Mean & Median \\
$\mathbf{2 0 0 4}$ & 166.59 & 102.52 & 93.52 & 72.23 & 230.52 & 128.70 \\
$\mathbf{2 0 0 5}$ & 143.51 & 101.77 & 86.53 & 72.10 & 192.16 & 127.59 \\
$\Delta \mathbf{2 0 0 5}$ & -26.27 & 0.00 & -7.00 & 0.00 & -43.13 & 0.00 \\
$\mathbf{2 0 0 6}$ & 143.20 & 103.01 & 86.52 & 70.09 & 194.66 & 149.85 \\
$\Delta \mathbf{2 0 0 6}$ & 5.09 & 2.99 & -0.08 & 0.69 & 9.78 & 4.74 \\
\hline
\end{tabular}

To get a better sense for the experience of the typical company in our sample, we calculate the ratio of net coverage to premium paid. Panel $B$ shows that Canadian-listed issuers get substantially more coverage for their premium dollar relative to their US-listed counterparts, suggesting that insurers calculate the probability of having to pay as being higher in the US. This ratio took a precipitous decline in 2005 , however, as Canadian-listed issuers lost an average of $\$ 43$ dollars in coverage for every premium dollar paid (22\%), while U.S. listed issuers had a much less substantial decline of $\$ 7$ in coverage per premium dollar paid $(7 \%)$. Simply put, firms listed in Canada were paying more and getting less in 2005 than they did in 2004. This pattern does not carry over to 2006; the ratio bounces back somewhat for Canadian-listed issuers in 2006, but the 2005 decline does not reverse itself.

The pattern may mirror some of the complexities involved in underwriting and pricing of insurance for directors, rather than simply the introduction of the new liability provisions, and hence only a portion is likely attributable to the introduction of a new liability regime. In Canada, the risk of director liability to date has been more pronounced in respect of environmental liability and pension liability, as two areas in which remedies have been successfully sought. Premia are priced through a complex formula. Although the publicly reported amounts indicate global shifts in 
premia and total coverage that could be compared to market cap, the data do not disclose the contours of the policy. Traditional D\&O policies did not contain many exclusions, and the exclusions that did exist, such as the misconduct exclusion, the improper profit exclusion, and claims for return of remuneration for which approval was not obtained, essentially mirrored the basic requirements for indemnification of directors and officers under corporations statutes. ${ }^{207} \mathrm{~A}$ leading Canadian insurance lawyer has observed that the market for insurers was quite limited until recently, and now a number of new entrants to the Canadian insurance market are competing for the same business with a consequent reduction in premia and the offering of new products. $^{208}$ She observes that part of directors' risk management strategy is to demand higher policy limits, written indemnity agreements and more effective coverage to backstop corporate indemnities and maximize personal asset protection through coverage that does not show up on the public disclosures of insurance coverage. Stitt notes, however, that common contractual limitations in D\&O insurance still exempt fraudulent acts or wilful violation of statutes and hence aligns with the type of conduct causing loss that is most likely to attract class action suits. ${ }^{209} \mathrm{An}$ important policy question is thus whether the availability of D\&O insurance is aligned with the policy objectives of civil liability provisions and whether the availability of insurance serves as an incentive, or not, in encouraging director and officer compliance with securities law requirements. The answer to this issue is not clear and deserves further study.

Baker and Griffith have suggested that in the US, the D\&O insurer serves as an important intermediary between injured shareholders and the managers who harmed them, as they tend to screen their risk pools, rejecting firms with the worst corporate governance practices and increasing the insurance premiums of firms with higher liability risk. ${ }^{210}$ Financial health and governance practices are two important determining factors in respect of insurance premia, and Baker and Griffith found that what matters to insurers are "deep governance" variables such as "culture", which is the system of incentives and constraints operating within the organization, including both formal rules and informal norms, and "character," which they define as the likelihood that top managers would defect from corporate interests when given an opportunity to do so, rather than formal governance structures. ${ }^{211}$ Second, they argue that D\&O insurers may monitor the governance practices of their corporate insured and seek to improve them by recommending changes, either as a condition to receiving a policy or in exchange for a reduction

${ }^{207}$ Stitt, supra, note 203 at 6; there have also been exclusions for pollution related claims. Gordon Hilliker, Liability Insurance in Canada, 3d Ed. (Vancouver, Butterworths, 2001) at 219. Generally, directors and officers may be indemnified if they acted honestly and in good faith with a view to the best interests of the corporation, and in the case of administrative or criminal action had reasonable grounds for believing that the conduct was lawful.

208 Telephone interview, Mary Jane Stitt, Blake Cassels and Graydon LLP, Toronto, March 2008.

209 Ibid.

210 Tom Baker and Sean J. Griffith, "Predicting Corporate Governance Risk: Evidence from the Directors' \& Officers' Liability Insurance Market” (2007) 74 University of Chicago Law Review at 8.

${ }^{211}$ Ibid. at 30-31. 
in premiums. ${ }^{212}$ Third, they suggest that $\mathrm{D} \& O$ insurers may manage the defence and settlement of shareholder claims, fighting frivolous claims, managing defence costs, and withholding insurance benefits from directors or officers who have engaged in actual fraud, and in this respect play a role in deterrence through the pricing and availability of insurance. ${ }^{213}$

In Canada, both the cost of D\&O premia and the availability of insurance will depend on both the kinds of cases that are brought forward and the remedies sought under the new securities law provisions, as well as under other remedial legislation, including the issue of whether the courts will allow officers to be indemnified by the company. Mary Jane Stitt observes that Canadian courts have historically distinguished between acts that are deliberate or performed recklessly and any unintended results, suggested that it is generally accepted in Canada, absent express policy wording stating otherwise, that an accident arises when the result is unintended, even if it might have been foreseen or even if it is the adverse outcome of a calculated risk. ${ }^{214}$ In US securities law cases, a number of courts have held that disgorgement is not an insurable loss, based on either interpretation of the specific insurance policy or public policy grounds, and it is not clear if Canadian courts will follow suit. ${ }^{215}$ Stitt observes that in Canada, D\&O policies now

212 Ibid. They suggest that public companies have about a 2 percent chance of being sued in a shareholder class action in any given year [Cornerstone Research, Securities Class Action Filings: 2005, A Year in Review 4 (2006), online at http://securities.stanford.edu/clearinghouse_research/2005_YIR/2006012302.pdf (visited Feb 9, 2007) (estimating susceptibility to a federal securities class action for "companies listed on the NYSE, Nasdaq, and Amex" at the start of 2005 at 2.4 percent). See also Ronald I. Miller, Todd Foster, and Elaine Buckberg, Recent Trends in Shareholder Class Action Litigation: Beyond the Mega-Settlements, is Stabilization Ahead? 3 (NERA Economic Consulting 2006), online at http://www.nera.com/image/BRO_RecentTrends2006_SEC979_PPB-FINAL.pdf (visited Feb 9, 2007) (estimating susceptibility of all publicly traded corporations in 2005 at 1.9 percent).

$213 \mathrm{lbid}$. at 47 . They also suggest that insurance underwriters take capital structure into account, suggesting, for example that a controlling shareholder may be a substitute for the governance constraints and significant insider share ownership may indicate an alignment of shareholder and management interests.

${ }^{214}$ Stitt, supra, note 203 at 30, citing Canadian Indemnity Company v. Walkem Machinery \& Equipment Ltd., [1976] 1 S.C.R. 309 (S.C.C).

215 Ibid. Stitt reports that the three major policy interpretation cases are Reliance Group Holdings Inc. $v$. National Union Fire Insurance Co. of Pittsburgh, Pa., 594 N.Y.S. 2d 20, 188 A.D. 2d 47 (App. Div. Dept.), leave to appeal dismissed in part, denied in part, 82 N.Y. 2d 704, 619 N.E. 2d 656, 601 N.Y.S. $2 d 578$ (N.Y. 1993) ("Reliance"), in which the New York Appellate Division found that there was no coverage available under a D\&O Policy where the insured had settled a series of derivative actions brought by shareholders alleging that various directors and officers had breached fiduciary duties by abandoning a hostile takeover in exchange for "greenmail" payments; Level 3 Communications, Inc. v. Federal Ins. Co., 272 F. $3^{\text {rd }} 908$ ( $7^{\text {th }}$ Cir. 2001) ("Level 3"), in which the $7^{\text {th }}$ Circuit refused coverage under a D\&O Policy in respect of the settlement of a securities fraud suit based on allegations of fraudulent misrepresentations, where the D\&O policy defined "Loss", in part, as: "damages, judgments, settlements and Defence Costs". Stitt observes that the $7^{\text {th }}$ Circuit found there was no coverage for the settlement payments made because the relief sought in the suit against Level 3 and for which indemnification was sought was restitutionary in nature; and Conseco, Inc. v. National Union Fire Ins. Co. of Pittsburgh, Pa., 2002 Extra Lexis 614, No. 49D130202CP00348 (Ind. Cir. Dec. 31, 2002), in which the Indiana Circuit Court held, in an unpublished opinion, that restitutionary damages assessed and/or paid pursuant to Section 11 of the Securities Act of 1933 did not constitute "Loss" under the relevant D\&O policies of insurance, as the Section 11 portion of a settlement that also involved claims under Section 10(b) of the Securities Exchange Act of 1934, represented "restitutionary damages", which corresponded to consideration which was wrongfully taken from the investing public. Thus, the court found that it was the restitutionary nature of the claim and the character of the settlement that controlled whether coverage was available, not the intent of the party forced to disgorge ill-gotten gains. 
exclude more types of claims because of increased litigation against directors and officers, including: (1) the "insured versus insured" exclusion, ${ }^{216}$ (2) the $10 \%$ principal shareholder exclusion, (3) the fiduciary liability exclusion, (4) matters covered under a commercial general liability (CGL) policy, ${ }^{217}$ and (5) claims for an accounting of profits made from the purchase or sale by an insured person of securities of the insured organization. Stitt suggests that the misconduct exclusion in a D\&O Policy excludes coverage for any claim based on allegations of any deliberately fraudulent act or omission or any wilful violation of any statute or regulation, if a judgment adverse to the insured person establishes such deliberately fraudulent act or omission or wilful violation. ${ }^{218}$ This misconduct exclusion is a powerful incentive for directors and officers to settle claims, rather than trying them to a judgment. In response to claims being made against directors and officers, insurers in North America have introduced further exclusions where they perceive increased risk in order to limit their exposure, and the contours of those exclusions are not apparent on the face of public disclosures. ${ }^{219}$ Hence, intentional misconduct is not covered by insurance, which is why in the US, insurance companies have been successful in persuading the courts that disgorgement is not an insurable loss. ${ }^{220}$ The issue has not yet been decided in Canadian courts, but may arise with new secondary market civil liability provisions.

Baker and Griffith suggest that liability insurers may play a part in the failings of the liability system by keeping the costs of shareholder litigation artificially low, given the high settlement rate within the limits of available insurance. ${ }^{221}$ The relationship between insurance and director and officer conduct is under-developed in the Canadian context, but should be an important policy consideration as the new civil liability regime is developed. It will be interesting to see if Canadian D\&O insurers begin taking the active role in governance described by US scholars. Insurers in Canada are clearly already heavily involved in decisions in respect of settlement of class action suits against directors and officers in the non-securities law context. ${ }^{222}$

\footnotetext{
${ }^{216}$ This exclusion excludes liability for loss on account of any claim made against any insured person brought or maintained on behalf of any insured (except derivative actions), ibid.

${ }^{217}$ Ibid.

218 Ibid.at 7-8.

219 Ibid. at 9. Stitt also observes that recent Ontario Court of Appeal decisions suggest that Canadian courts will apply the fortuity principle and other overarching guiding principles when interpreting D\&O and fiduciary liability policies to limit the types of financial exposures that are covered, although a very recent decision of the same court suggests that these principles are only "interpretative aids" that must yield to the express language of the policies. The fortuity principle suggests that "insurance is a mechanism for transferring fortuitous contingent risks...Insurance usually makes economic sense only where the losses covered are unforeseen or accidental", Non-Marine Underwriters, Lloyds of London v. Scalera, [2001\} 1 S.C.R. 551 at 568; and "ordinarily only fortuitous or contingent losses are covered by a liability policy. When an insured intends to cause the very harm that gives rise to the claim, the insured cannot look to a liability policy for an indemnity"; Liberty Mutual Insurance Co. v. Hollinger Inc., [2004] O.J. 481 Ont. C.A. (13 February 2004).

220 Ibid. at 34, citing a number of US authorities.

${ }^{221}$ Baker and Griffiths, supra, note 7 at 49.

222 Stitt, supra, note 203.
} 
A related issue is one of indemnification by the company itself and whether a director or officer is entitled to indemnification, and which side has the onus of establishing whether or not there was honesty, good faith and belief in lawful conduct, the criteria to be met for indemnification under Canadian corporate law. ${ }^{223}$ The Ontario Superior Court of Justice decision recently allowed a claim for indemnification by a CEO and president of a company, Bennett, with respect to expenses incurred in civil and administrative proceedings pursuant to the Canada Business Corporations Act. $^{224}$ The expenses were incurred as a result of the officer defending himself in a consolidated class action in the US and securities regulatory proceedings in Canada and the US in respect of allegations of failure to disclose material change on a timely basis. All the proceedings resulted in settlement. The class actions settled for a cash payment of $\$ 9.75$ million USD, of which the company paid $\$ 0.75$ million and the insurer paid the rest. ${ }^{225}$ The securities proceedings were settled by agreement that Bennett was prohibited from acting as a director for ten years, fined $\$ 250,000$ as an administrative fine, and ordered to pay $\$ 50,000$ towards the commission's investigation costs. ${ }^{226}$ Bennett admitted, subject to certain caveats, to violations of the Ontario Securities Act in failing to disclose material information on a timely basis. ${ }^{227}$ The board of directors made a decision that Bennett had not complied with the good faith or lawful conduct requirements for indemnification and sought repayment of all the funds advanced in the proceedings. The Court, following the Supreme Court of Canada in Blair v. Consolidated Enfield, ${ }^{228}$ held that the burden lies on the company to prove bad faith. The Court also held that bad faith is not restricted to intentional fault, but can include wanton or reckless conduct. ${ }^{229}$ The Court held that while Bennett, at the time, had a reasonable basis for his belief, it was to be distinguished from understanding in retrospect that his conduct fell below the statutory standard. ${ }^{230}$ Here, the Court found no expert evidence or other evidence that would lead to a conclusion that Bennett's beliefs were unfounded or totally unreasonable and hence the Court held that the company failed to discharge the burden of establishing that Bennett acted in bad faith or unlawfully. ${ }^{231}$

The judgment is interesting, in that it finds that although the officer admitted in the settlement to violating the statute, it is not, in itself, sufficient to establish that he was not entitled to indemnification. Leave is being sought to appeal the judgment, the issue likely to be whether or not the court improperly imported a subjective element into the objective test of director

${ }^{223}$ See for example, s. 124, Canada Business Corporations Act.

${ }^{224}$ John Anthony Bennett v. Bennett Environmental Inc., decision of C. Campbell J, (4 March 2008), Ontario Superior Court of Justice, Court file 07-CL-7054.

${ }_{225}$ Ibid. at para. 11.

${ }^{226} \mathrm{Ibid}$. at para. 18.

227 Ibid. at para. 17.

${ }^{228}$ Blair v. Consolidated Enfield, [1995] S.C.R. 29.

229 John Anthony Bennett v. Bennett Environmental Inc., supra, note 223 at para. 41.

${ }^{230} \mathrm{Ibid}$. at para. 51.

${ }^{231} \mathrm{Ibid}$. at para. 53. 
obligations, as the Court held that "a director will be held to an objective standard of care in carrying out his duties but there is as well a subjective element that takes into account the individual skill and training and the circumstances surrounding his or her action", ${ }^{232}$ and the issue of whether an admission of violation of statutory requirements is sufficient for a company to refuse to indemnify its officers. ${ }^{233}$ Whatever the result, it will be a significant decision for future ability to settle cases and for the scope of potential personal liability for directors and officers for securities law violations.

\section{Conclusion}

Canadian securities markets have entered a new era with the introduction of private causes of action. The legislation, as enacted, reflects a careful consideration of the costs and benefits of such actions. In this, it stands in sharp contrast to the parallel cause of action in the US: Rule $10 \mathrm{~b}-5$ is an awkward amalgamation of a judicially created cause of action with legislative limits subsequently imposed to rein in what was perceived to be abusive litigation. In particular, the Canadian legislation, by eliminating the reliance requirement, avoids the unintended consequences of the "fraud-on-the-market" theory of reliance used in the US, which tends to skew private enforcement toward the largest companies with the most actively-traded shares. Active trading is likely to correlate with widespread analyst coverage, one check against fraud.

The overall litigation exposure for Canadian companies remains relatively low when compared to their counterparts in the US. Canadian issuers that have listed their shares in the US face the greatest litigation exposure, and such lawsuits are substantially more costly to resolve. Larger companies are more likely to be sued even under the Canadian legislation because they promise larger damage awards, a key factor explaining the incidence of suit. The Canadian legislation limits liability for garden-variety misrepresentations to $5 \%$ of market capitalization, so no company is likely to face bankrupting liability for an innocent mistake. The liability cap is lifted, however, for cases of intentional fraud; we see the effects of this exception in the high percentage of cases against companies that have been subjected to a government investigation or had to restate their earnings. Clearly, these are the frauds that policymakers should be most anxious to deter, so this targeting is somewhat reassuring. On the other hand, these factors are also the most public indications of fraud, so these companies have already been subject to a stiff sanction in the stock market when the restatement or government investigation was first revealed.

\footnotetext{
232 Ibid., citing the Supreme Court of Canada in Peoples Department Stores, supra, note 49.

233 Ibid. at para. 47.
} 
One potential effect of the new secondary market legislation is that it might tend to equalize the burden of class actions between Canadian firms that are listed only in Canada and those that are listed in the US. The shift in D\&O rates that we document from 2004 to 2005 tends to support this view, although, as noted above, the complex factors that determine insurance rates do not allow us to establish direct causation. The equalization is unlikely to be complete, however, because Canadian firms listed in the US now face litigation exposure in both jurisdictions. Although the number of such cases remains relatively small, the cross-border suits do appear to be very expensive to resolve, with mean settlements considerably greater than settlement amounts for suits brought only in one jurisdiction or the other. A critical factor likely to affect the usage of the new class action legislation will be the jurisdiction in which the suit is filed and judicial decisions relating to costs. The Supreme Court's recent decision in Danier Leather is sure to be a caution to plaintiffs and their lawyers who are considering the possibility of suit in a jurisdiction that has not adopted the no-cost regime for class action proceedings.

As the foregoing discussion illustrates, a number of factors are exerting contrary influences over the level of litigation and subject matter, including the expanded pool of potential defendants in secondary market civil liability actions, the availability of class action proceedings, Canada's loser-pays costs regime, requirements for leave, liability caps and the availability of insurance and indemnity. It will be worth investigating how the forthcoming decisions of the courts in certification and leave proceedings affect these factors and their interaction in Canadian securities law enforcement. For the time being, Canadian issuers face considerable uncertainty over the extent of their exposure to securities class actions. 
Appendix A

Comparative Summary of Primary Market Civil Liability Provisions

\begin{tabular}{|c|c|c|}
\hline Primary Market & Canada & United States \\
\hline $\begin{array}{l}\text { Those with cause } \\
\text { of action }\end{array}$ & $\begin{array}{l}\text {-Purchaser of securities during the period of distribution where a } \\
\text { prospectus or amendment to prospectus, offering memorandum, } \\
\text { contains a misrepresentation } \\
\text {-Security holder where take-over bid or notice of change or } \\
\text { variation contains a misrepresentation }\end{array}$ & $\begin{array}{l}\text {-Purchaser of securities traceable to a registration } \\
\text { statement, recipients of the prospectus, if either } \\
\text { contains a misrepresentation } \\
\text {-Security holder for misrepresentation made in } \\
\text { connection with a tender offer }\end{array}$ \\
\hline Class of defendants & $\begin{array}{l}\text {-The issuer, or, in the case of a sale by a control person, against } \\
\text { the selling security holder. } \\
\text {-Directors of the issuer at the time the prospectus or amendment } \\
\text { to a prospectus was filed } \\
\text {-Underwriter } \\
\text {-Any expert who gave her or his consent to the use of all or part } \\
\text { of her or his opinion or report } \\
\text {-Every person who signed the prospectus }\end{array}$ & $\begin{array}{l}\text {-The issuer } \\
\text { - Directors of the issuer at the time the registration } \\
\text { statement or amendment was filed } \\
\text {-Underwriter } \\
\text {-Any expert who gave her or his consent to the use of } \\
\text { all or part of her or his opinion or report } \\
\text {-Every person who signed the registration statement } \\
\text { (includes CEO and CFO) }\end{array}$ \\
\hline Burden of Proof & $\begin{array}{l}\text {-Deemed reliance - the plaintiff does not have to establish either } \\
\text { the existence of a duty of care or reliance on the } \\
\text { misrepresentation if it was a misrepresentation at the time the } \\
\text { security was purchased } \\
\text {-The plaintiff must demonstrate that he or she purchased the } \\
\text { security offered under the prospectus; the purchase was made } \\
\text { during the period of distribution; and that there was a } \\
\text { misrepresentation in the prospectus. }\end{array}$ & $\begin{array}{l}\text {-No reliance requirement } \\
\text {-The plaintiff must demonstrate that he or she } \\
\text { purchased securities traceable to the registration } \\
\text { statement, or received a prospectus, which contained a } \\
\text { misrepresentation }\end{array}$ \\
\hline $\begin{array}{l}\text { Remedy/Damages } \\
\text { (limits on liability) }\end{array}$ & $\begin{array}{l}\text {-Rescission or damages } \\
\text {-No underwriter is liable for more than the total public offering } \\
\text { price underwritten by it } \\
\text {-Amount recoverable is not to exceed the price at which the } \\
\text { securities were offered to the public. } \\
\text {-In action for damages, the defendant is not liable for any portion } \\
\text { of the damages that the defendant proves does not represent the } \\
\text { depreciation in value of the security as a result of the } \\
\text { misrepresentation. } \\
\text {-Joint and several liability }\end{array}$ & $\begin{array}{l}\text {-Rescission or damages } \\
\text {-No underwriter is liable for more than the total public } \\
\text { offering price underwritten by it } \\
\text {-Amount recoverable is not to exceed the price at which } \\
\text { the securities were offered to the public. } \\
\text {-In action for damages, the defendant is not liable for } \\
\text { any portion of the damages that the defendant proves } \\
\text { does not represent the depreciation in value of the } \\
\text { security as a result of the misrepresentation. } \\
\text {-Joint and several liability; proportionate liability for } \\
\text { outside directors }\end{array}$ \\
\hline Defences & $\begin{array}{l}\text {-Plaintiff had knowledge of the misrepresentation and the } \\
\text { misrepresentation did not cause the loss. } \\
\text {-Due diligence defence, defendant must show that he or she } \\
\text { conducted a reasonable investigation to provide reasonable } \\
\text { grounds for a belief that there was no misrepresentation and that } \\
\text { he or she did not believe that there was misrepresentation. } \\
\text {-Defendant is not liable for any part of a prospectus or } \\
\text { amendment to a prospectus based on a report, opinion or } \\
\text { statement of an expert where the defendant had no reasonable } \\
\text { grounds to believe and did not believe that there had been a } \\
\text { misrepresentation. } \\
\text {-Defendant either did not consent to the filing of prospectus or } \\
\text { withdrew consent prior to the purchase of the securities by the } \\
\text { purchaser and gave reasonable general notice of and reasons } \\
\text { for such withdrawal. } \\
\text {-Experts- duty of reasonable investigation with respect to that } \\
\text { part of the prospectus prepared on their own authority as } \\
\text { experts. } \\
\text {-Issuer of the securities or selling security holder strictly liable for } \\
\text { misrepresentations in a prospectus } \\
\text {-Where the defendant is a person in a special relationship, the } \\
\text { person has a defence where proves that the person reasonably } \\
\text { believed that the material fact or change had generally been } \\
\text { disclosed or the material fact or change was known or ought } \\
\text { reasonably to have been known by the seller or purchaser }\end{array}$ & $\begin{array}{l}\text {-Plaintiff had knowledge of the misrepresentation and } \\
\text { the misrepresentation did not cause the loss. } \\
\text {-Due diligence defence, defendant must show that he } \\
\text { or she conducted a reasonable investigation to provide } \\
\text { reasonable grounds for a belief that there was no } \\
\text { misrepresentation and that he or she did not believe } \\
\text { that there was misrepresentation. } \\
\text {-Defendant is not liable for any part of a registration } \\
\text { statement or amendment based on a report, opinion or } \\
\text { statement of an expert where the defendant had no } \\
\text { reasonable grounds to believe and did not believe that } \\
\text { there had been a misrepresentation. } \\
\text {-Defendant either did not consent to the filing of } \\
\text { registration statement or withdrew consent prior to the } \\
\text { purchase of the securities by the purchaser and gave } \\
\text { reasonable general notice of and reasons for such } \\
\text { withdrawal. } \\
\text {-Experts- duty of reasonable investigation with respect } \\
\text { to that part of the registration statement prepared on } \\
\text { their own authority as experts. } \\
\text {-Issuer of the securities or selling security holder strictly } \\
\text { liable for misrepresentations in a registration statement } \\
\text {-All defendants have a defence of reasonable care for } \\
\text { misstatements in a prospectus }\end{array}$ \\
\hline Limitation Period & $\begin{array}{l}\text {-Action for rescission must be brought within } 180 \text { days from the } \\
\text { date of the transaction that gave rise to the cause of action. } \\
\text {-Action for damages, the action must be brought from the earlier } \\
\text { of } 180 \text { days from the date the plaintiff had knowledge of the facts } \\
\text { giving rise to the cause of action and three years from the date of } \\
\text { the transaction }\end{array}$ & $\begin{array}{l}\text {-Action must be brought from the earlier of } 1 \text { year from } \\
\text { the date the plaintiff had knowledge of the facts giving } \\
\text { rise to the cause of action and three years from the } \\
\text { date of the transaction }\end{array}$ \\
\hline
\end{tabular}


Appendix B

Comparative Summary of Secondary Market Civil Liability Provisions

\begin{tabular}{|c|c|c|}
\hline Secondary Market & Canada & United States \\
\hline $\begin{array}{l}\text { Those with cause } \\
\text { of action }\end{array}$ & $\begin{array}{l}\text {-Person or company who acquires or disposes of the issuer's } \\
\text { securities between the time document was released or public } \\
\text { oral statement made that contained the misrepresentation and } \\
\text { the time the misrepresentation was publicly corrected } \\
\text {-For failure to make timely disclosure, a person or company who } \\
\text { acquired or disposed of the securities between the time material } \\
\text { change was required to be disclosed and its disclosure. }\end{array}$ & $\begin{array}{l}\text {-Person or company who acquires or disposes of the } \\
\text { issuer's securities between the time document was } \\
\text { released or public oral statement made that contained } \\
\text { the misrepresentation and the time the } \\
\text { misrepresentation was publicly corrected }\end{array}$ \\
\hline Class of defendants & $\begin{array}{l}\text {-The responsible issuer, directors and officers, "influential } \\
\text { persons" and, in the case of written documents or oral } \\
\text { statements, experts where misrepresentation in report, opinion. } \\
\text {-Influential person includes control persons, promoters, and } \\
\text { insiders who are not directors or senior officers However, } \\
\text { unless the influential person released the impugned document or } \\
\text { made the public oral statement, knowing influence on the issuer } \\
\text { required to ground an action } \\
\text {-If the person who made the public oral statement that is } \\
\text { impugned had apparent authority, but not implied or actual } \\
\text { authority, others not liable }\end{array}$ & $\begin{array}{l}\text { - Anyone who makes a misstatement or commits a } \\
\text { manipulative act } \\
\text {-Control persons, unless they can show that they acted } \\
\text { in good faith and did not induce the violation }\end{array}$ \\
\hline Burden of Proof & $\begin{array}{l}\text { Deemed reliance -no requirement for the plaintiff to demonstrate } \\
\text { reliance on the misrepresentation, or on the issuer having } \\
\text { complied with timely disclosure requirements } \\
\text {-Distinction between core and non-core documents } \\
\text {-Requires a higher burden of proof on plaintiff where non-officer } \\
\text { directors and influential persons are being sued with respect to } \\
\text { non-core documents or public oral statements; must prove knew } \\
\text { at the time that contained misrepresentation or deliberately } \\
\text { avoided acquiring the knowledge, or guilty of gross misconduct } \\
\text {-Elevated burden of proof also required where directors and } \\
\text { influential persons sued for failure to make timely disclosure, } \\
\text { knew change was material; deliberately avoided acquiring } \\
\text { knowledge; gross misconduct } \\
\text {-Higher burden re timely disclosure not apply to issuer or officers } \\
\text {-Liability limits inapplicable (except for the responsible issuer) } \\
\text { where the plaintiff can prove the defendant authorized, permitted } \\
\text { or acquiesced in making the misrepresentation or failure to make } \\
\text { timely disclosure while knowing of misrepresentation or failure to } \\
\text { make timely disclosure or influenced making misrepresentation } \\
\text { or the failure to make timely disclosure while knowing it was } \\
\text { misrepresentation or failure to make timely disclosure. }\end{array}$ & $\begin{array}{l}\text {-Presumption of reliance; for omissions in breach of a } \\
\text { duty to disclose, plaintiff must show materiality, for } \\
\text { affirmative misstatements, plaintiff must demonstrate } \\
\text { that stock traded in a liquid capital market that rapidly } \\
\text { incorporates information } \\
\text {-Plaintiff must plead and prove recklessness for } \\
\text { misstatement of historical fact and knowledge for false } \\
\text { forward-looking statements } \\
\text {-Plaintiff must plead and prove that misrepresentation } \\
\text { was the cause of the loss }\end{array}$ \\
\hline $\begin{array}{l}\text { Damages (limits on } \\
\text { liability) }\end{array}$ & $\begin{array}{l}\text {-Limits the damages for issuer or non-individual influential } \\
\text { person to the greater of } \$ 1 \text { million or } 5 \% \text { of the issuer's market } \\
\text { capitalization. } \\
\text {-Limits damages payable by individual influential person, officer } \\
\text { or director of the issuer or of the influential person to the greater } \\
\text { of } \$ 25,000 \text { or } 50 \% \text { of aggregate compensation from issuer } \\
\text {-Expert, greater of } \$ 1 \text { million and revenue that earned from the } \\
\text { issuer and its affiliates in } 12 \text { months prior } \\
\text {-person making oral public statement, } \$ 25,000 \text { or } 50 \% \text { of } \\
\text { aggregate compensation from issuer } \\
\text {-Liability is also to be proportionate with respect to each } \\
\text { defendant's responsibility for the damages assessed. } \\
\text {-Joint and several liability }\end{array}$ & $\begin{array}{l}\text {-No damages limit } \\
\text {-Proportionate liability for reckless misstatements, joint } \\
\text { and several liability for knowing misstatements }\end{array}$ \\
\hline Defences & $\begin{array}{l}\text {-Plaintiff knew of the misrepresentation or material change } \\
\text {-Reliance on experts } \\
\text {-Reasonable investigation, no reasonable ground to believe a } \\
\text { misrepresentation } \\
\text {-Making confidential disclosure to regulator, if reasonable basis } \\
\text {-FOFI if reasonable cautionary language and reasonable basis } \\
\text { for drawing the conclusions } \\
\text {-Due diligence defence, burden of proof on defendant. } \\
\text { Legislative provisions enumerate a variety of factors that should } \\
\text { be considered by a court in determining whether the defendant } \\
\text { undertook a reasonable investigation or is guilty of gross } \\
\text { misconduct } \\
\text {-Existence and nature of any system designed to ensure that } \\
\text { issuer meets its continuous disclosure obligations } \\
\text {-If proves did not know and had no reasonable grounds to } \\
\text { believe the document would be released } \\
\text {-Derivative information and where corrective action taken }\end{array}$ & $\begin{array}{l}\text {-Forward-looking information if accompanied by } \\
\text { meaningful cautionary language }\end{array}$ \\
\hline Limitation Period & $\begin{array}{l}\text {-No later than earlier of } 3 \text { years after document containing } \\
\text { misrepresentation released, public oral statement, or failure to } \\
\text { make timely disclosure; and } 6 \text { months after news release that } \\
\text { leave granted to commence an action }\end{array}$ & $\begin{array}{l}\text {-No later than earlier of } 5 \text { years after misrepresentation } \\
\text { and } 2 \text { years after fraud discovered }\end{array}$ \\
\hline
\end{tabular}

